\title{
IP-Based Incentives Against Antimicrobial Crisis: A European Perspective
}

\author{
Pedro Henrique D. Batista · Dennis Byrski • \\ Matthias Lamping • Roberto Romandini
}

Published online: 16 January 2019

(C) The Author(s) 2019

\begin{abstract}
The field of antimicrobials is considered to be facing a crisis. Increasing microbial resistance is creating a demand for new drugs, which however is not being matched by privately funded $R \& D$. The reasons for this market failure are of a technical and economic nature. The present article analyzes what changes to IPbased incentives are conceivable in the European Union (EU) in order to address the antimicrobial crisis. Since the assessment of the suitability of the analyzed options depends on interdisciplinary research, this article also proposes a research agenda to be considered for the implementation of public policies in this field.
\end{abstract}

\footnotetext{
The authors have jointly conceived the paper and share the views expressed therein. Nonetheless, while the conclusions are attributable to all authors (Sect. 6), Sect. 1 is specifically attributable to Batista and Romandini, Sect. 2 to Batista, Sect. 3 to Lamping, Sect. 4 to Romandini and Sect. 5 to Batista (5.1-5.2) and Byrski (5.3).
}

\author{
P. H. D. Batista ( $($ ) \\ LL.M. (Munich); Doctoral Student and Junior Research Fellow, Max Planck Institute for Innovation \\ and Competition, Munich, Germany \\ e-mail: pedro.batista@ip.mpg.de \\ D. Byrski \\ M.Sc.; Doctoral Student and Junior Research Fellow, Max Planck Institute for Innovation and \\ Competition, Munich, Germany \\ e-mail: dennis.byrski@ip.mpg.de
}

\section{Lamping}

Dr. jur.; Senior Research Fellow, Max Planck Institute for Innovation and Competition, Munich, Germany

e-mail: matthias.lamping@ip.mpg.de

R. Romandini

Dr. jur.; LL.M. (Munich); Senior Research Fellow, Max Planck Institute for Innovation and Competition, Munich, Germany

e-mail: roberto.romandini@ip.mpg.de 
Keywords Antimicrobials - Antibiotics - Incentives - Transferable exclusivities ·

Wild card $\cdot$ Research agenda

\section{Introduction}

Patent rights are designed to confer only a market opportunity: ${ }^{1}$ they create a chance for patent owners to obtain higher returns for products or services incorporating the patented invention, ${ }^{2}$ since the latter are not exposed to competition that follows from literal or equivalent ${ }^{3}$ embodiments of the claimed technical solution. The same conclusion applies - mutatis mutandis - to other forms of IP incentives or IP-like incentives, such as supplementary protection certificates (SPCs), utility models or data exclusivity.

Whether the opportunity is realized depends on the commercial success of the patent-protected product. This mechanism has several virtues. It leaves it to the market actors to define what products will be developed and to the users how large the reward will be. Consequently, it frees patent offices from determining ex ante the value of an innovation. It does not interfere with a market-oriented allocation of resources and, in principle, it avoids a mismatch between the amount of the reward and the market value of the innovation concerned. Finally, it creates incentives for both invention and innovation: since the patentee can only obtain a return when a product or service incorporating the technical teaching is brought to the market, he/ she has an interest in making this possible by investing directly in the development of a marketable product, or by licensing the technology or transferring the patent. ${ }^{4}$

Such a mechanism, however, also has shortcomings. Where a specific solution is needed, but the market demand or reward for it is not sufficiently large to make research profitable, or where state policies restrain the use of the technology concerned, patents are ineffective.

One example where IP-based incentives are perceived as not satisfactory to generate sufficient urgently needed innovation, and where all these factors seem to meet in an unfortunate marriage of inconvenience is the field of antimicrobials. Due to the natural development of microbial resistance, there is an increasing need for new antimicrobials to treat the most diverse types of infections, sepsis and further diseases. ${ }^{5}$ The market, however, has not responded to this need. Conversely, a slowdown in innovation in this field has been observed. ${ }^{6}$

Scholarly contributions associate this market failure with the absence of economic incentives for investments in antimicrobial research, which mainly derives from three factors: health policies aimed at reducing or delaying the use of

\footnotetext{
${ }^{1}$ Kraßer and Ann (2016), § 3 para. 17 et seq.

2 Duffy (2004), p. 439.

3 See Art. 69 EPC.

4 Such a mechanism does not work when the patentee has reason to expect that products incorporating the invention will be on the market anyway, because the implementation of the invention is necessary to market a specific category of products (for instance, to comply with a technical standard).

5 See Sect. 2.1 below.

6 World Health Organization (2017a), p. 12.
} 
new antimicrobials; the limited period of time in which an antimicrobial is used for treatments (up to two weeks); and the reduction of the market lifetime of a drug due to microbial resistance. ${ }^{7}$

The purpose of this article is to address the question whether and to what extent changes to IP-based incentives can cure this deficiency from a European perspective. The timing for consideration of this issue seems appropriate. On the one hand, in the USA, bills are pending and initiatives are being discussed, which are directed at adopting wild-card incentives for antimicrobials, a new form of IP-based incentive. ${ }^{8}$ On the other hand, in a recent resolution the EU Parliament has called on the Member States to consider "transferable market exclusivities" (alongside "market entry rewards") as options for sustainable incentives. ${ }^{9}$ Finally, in the recent review of the SPC legislation, the EU Commission itself has posed the research question whether and to what extent adaptions to the SPC legislation could foster more innovation in this field. ${ }^{10}$

While this article does not intend to advance a specific answer, it aims at framing an agenda for future multidisciplinary research. In accordance with this aim, the discussion will proceed as follows. Section 2 will detail the possible reasons for the assumed antimicrobial crisis. Section 3 will review from a theoretical point of view the different tools for incentivizing antimicrobial research and sum up the traditional division in pull and push incentives. Section 4 will focus on IP-based incentives and the related options for the lawmakers. Section 5 will identify some questions for interdisciplinary research in the field of antimicrobials.

\section{The Antimicrobial Crisis}

According to several contributions, antimicrobials are considered to be a field in crisis in the pharmaceutical sector. ${ }^{11}$ This crisis is mainly attributed to increasing antimicrobial resistance (2.1) - which boosts demand for new antimicrobial agents - and the absence of sufficient innovation to meet this demand (2.2). Both factors are connected.

\subsection{Antimicrobial Resistance}

Antimicrobial resistance is the ability of certain living microorganisms to withstand the use of chemical agents that aim to eliminate them or suppress their growth. ${ }^{12}$ On the one hand, resistance can be caused by factors inherent to the constitution of the

\footnotetext{
7 See Sect. 2.2 below.

${ }^{8}$ H.R. 6294 (Re-Valuing Anti-Microbial Products Act of 2018 - REVAMP Act). Available at https:// www.congress.gov/bill/115th-congress/house-bill/6294/text (accessed 25 Nov 2018).

9 European Parliament, European Parliament resolution of 13 September 2018 on a European One Health Action Plan against Antimicrobial Resistance (AMR) (2017/2254(INI)), P8_TA-PROV(2018)0354, Recital 111.

10 See Batista and Romandini (2018), p. 435 et seq.

11 See, for instance, Gollaher and Milner (2012), p. 12 et seq.; Spellberg et al. (2007), p. 167; Lee Ventola (2015), p. 277 et seq.; Sengupta et al. (2013); Kesselheim and Outterson (2010), p. 1689 et seq.

12 See comparable definitions by the US National Institute of Allergy and Infectious Diseases, available at https://www.niaid.nih.gov/research/antimicrobial-resistance-definitions (accessed 12 Nov 2018) and by
} 
microorganisms. Different bacteria may, for instance, produce substances that inactivate antimicrobial agents, reduce their membrane permeability in order to avoid antimicrobial effects, expel antimicrobials from the cell, overproduce target enzymes, bypass the inhibited step or simply change the area of action of the antimicrobial agent. ${ }^{13}$ Further, they can withstand antimicrobial treatment by entering a slow, non-multiplying state, ${ }^{14}$ then becoming active again after the treatment ends. On the other hand, resistance can be transmitted between microorganisms through horizontal gene transfers (HGT). ${ }^{15}$ In such a case, microorganisms that are not originally immune to a particular treatment can become resistant through genetic mutations caused by HGT. ${ }^{16}$ Although the resistance transferred is more likely to reduce the effects of antimicrobial agents of the same class, that is, those with a common target and spectrum of action in the microorganism concerned, ${ }^{17}$ crossresistance between different antimicrobial classes is also possible when the bacterium hosts genes containing resistance to other antimicrobial classes (multi-resistance). ${ }^{18}$

The use of antimicrobial agents contributes to the increase in antimicrobial resistance. Considering the natural selection process, only resistant microorganisms can survive after an antimicrobial treatment. ${ }^{19}$ These remaining microorganisms are then capable not only of rapidly proliferating, but also of transferring their resistance genetically by HGT, which increases resistance rates. The misuse and the overuse of antimicrobials (e.g. unnecessary prescription in cases of viral or noninfectious diseases, prescription of doses higher than necessary, under-treatment through suboptimal doses, inadequate treatment durations, and extensive agricultural and veterinary use $)^{20}$ are therefore considered to be critical factors in this field.

The problem of antimicrobial resistance cannot be underestimated. According to a recent study on infections caused by resistant bacteria in the EU and the European Economic Area, more than 670,000 infections were recorded in these countries during the year 2015, which were responsible for more than 33,000 deaths. ${ }^{21}$ The problem mainly affects Southern European countries, such as Greece and Italy, although countries like Romania, Portugal, Hungary and Germany also have relatively high numbers of infections. ${ }^{22}$ The majority of the population affected by these infections is composed of infants and persons aged 65 years or older. ${ }^{23}$

\footnotetext{
Footnote 12 continued

the World Health Organization, available at https://www.who.int/features/qa/75/en/ (accessed 12 Nov 2018).

13 Coates et al. (2011).

14 Ibid.

15 Lee Ventola (2015), p. 277 et seq.; Sengupta et al. (2013).

16 Batista and Romandini (2018), p. 436.

17 Angulo et al. (2009), p. 132 et seq.

18 French Agency for Food, Environmental and Occupation Health and Safety (2014), p. 4.

19 Sengupta et al. (2013); Lee Ventola (2015), p. 277 et seq.

20 See Kesselheim and Outterson (2010), p. 1690; Horowitz and Moehring (2004), p. 577; Outterson et al. (2007), p. 564; Lee Ventola (2015), p. 277 et seq.; Sengupta et al. (2013).

21 Cassini et al. (2018), p. 5.

22 Ibid., p. 7.

23 Ibid., p. 6.
} 
According to the European Commission, treating microbial infections costs on average 1.5 billion euros per year. ${ }^{24}$ The problem does not only occur in Europe. In the US, it is estimated that more than 23,000 people die annually from antimicrobial resistance. ${ }^{25}$ The recently published Global Antimicrobial Resistance Surveillance System (GLASS) Report by the World Health Organization indicates that the problem also severely afflicts other countries. ${ }^{26}$

A particular challenge in this field is fighting gram-negative bacteria, such as Klebsiella pneumoniae ${ }^{27}$ Escherichia Coli, Pseudomonas aeruginosa, Acinetobacter baumannii and the family of Enterobacteriaceae. ${ }^{28}$ Mainly because of the particular structure of their cell walls, ${ }^{29}$ these pathogens are extensively drug- and multidrug-resistant. ${ }^{30}$ They are responsible for the most so-called priority diseases in the antimicrobial field, ${ }^{31}$ which reach a large number of people and cannot be treated effectively with existing antimicrobial agents.

At this point, it is worth noting that not all new antimicrobial agents would be able to promote real advances against the antimicrobial crisis. New antimicrobials belonging to existing classes would be more susceptible to rapid cross-resistance. ${ }^{32}$ For this reason, the literature indicates that qualified innovation is needed, ${ }^{33}$ such as new agents that are able to attack new targets or offer new mechanisms of action in microbial cells. ${ }^{34}$ The definition of what type of research is needed is material to guide future public policies in the field of antibiotics and to avoid economic costs that are not in adequate relationship with the social benefits of the innovation rewarded. $^{35}$ This task, including the consideration of practical challenges to implementing the policy - such as bureaucracy, market pressure, technical definition of criteria etc. $-{ }^{36}$ is not the purpose of this article, though it is included in the research agenda suggested below. ${ }^{37}$

Beyond the quality of the innovation required, some scholars have recently critically addressed the degree, effects and forms of dealing with antimicrobial resistance. According to them, the dimension of the antimicrobial crisis is smaller than indicated by most authors. This assumption is based primarily on the fact that

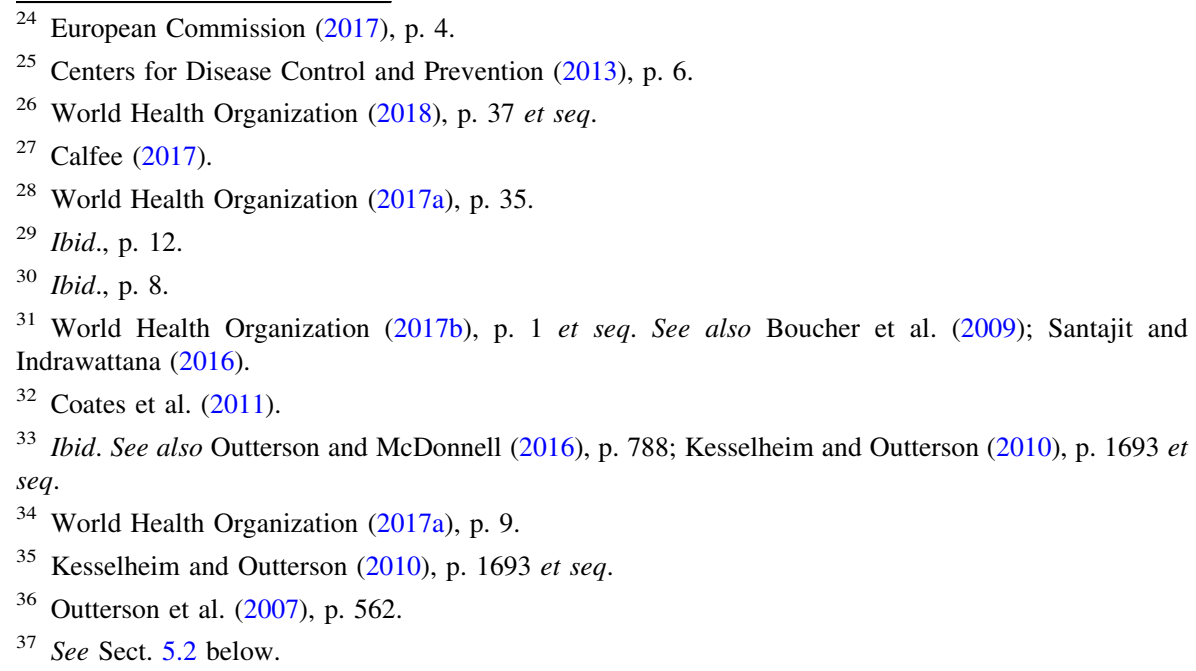


the performance and virulence of resistant bacteria can be lower under certain conditions. ${ }^{38}$ Further, there are uncertainties about the trajectories of resistant bacteria and about the biological relation between lower utilization of antimicrobials and bacterial resistance reduction. ${ }^{39}$ Evidence of low levels or even of a decrease in bacterial resistance without a satisfactory scientific explanation increases skepticism about the scale of the crisis. ${ }^{40}$ Moreover, there are doubts about the methods of identifying the number of infections and deaths indicated in research on antimicrobial resistance. ${ }^{41}$ In addition, the demand for new antimicrobials is also disputable, since - according to recent studies - both old antibiotics and antibiotic adjuvants, which can enhance the activity of already existing antibiotics, can be used to minimize and block resistance. ${ }^{42}$

A critical appraisal of this technical discussion goes beyond the objectives of this article and also the skills of its authors. Of course, these aspects must be part of an interdisciplinary research agenda that shall guide future steps in the regulation of antimicrobials. $^{43}$

\subsection{Lack of Innovation}

The demand for new antimicrobials does not find a corresponding supply on the pharmaceutical market. After a great wave of innovation between the 1940s and 1980s, in which several antimicrobial agents and classes were invented, ${ }^{44}$ the subsequent period did not witness such a sharp innovation curve, especially in the case of new antimicrobial classes, which, at least at first, would be less susceptible to resistance. More optimistic authors do not see a crisis in this reduction and emphasize the relevance of the innovations in the early 2000s. ${ }^{45}$ However, comparisons with the number of new antimicrobial agents and classes in the previous period and the absence of a market reaction to the growing demand for new antimicrobials justify a more critical view in this area. A recent study conducted by the World Health Organization indicates, for instance, that of all 51 antibiotics in the clinical pipeline in May 2017, only nine belong to five new classes, and that even if the related clinical trials were successful, there would still be a lack of potential treatment options against gram-negative bacteria. ${ }^{46}$

The reasons for this apparent market failure are of a technical and economic nature.

From the technical point of view, some scholars indicate that the prospects for innovation in the antimicrobial field are reduced, since there is a shortage of new

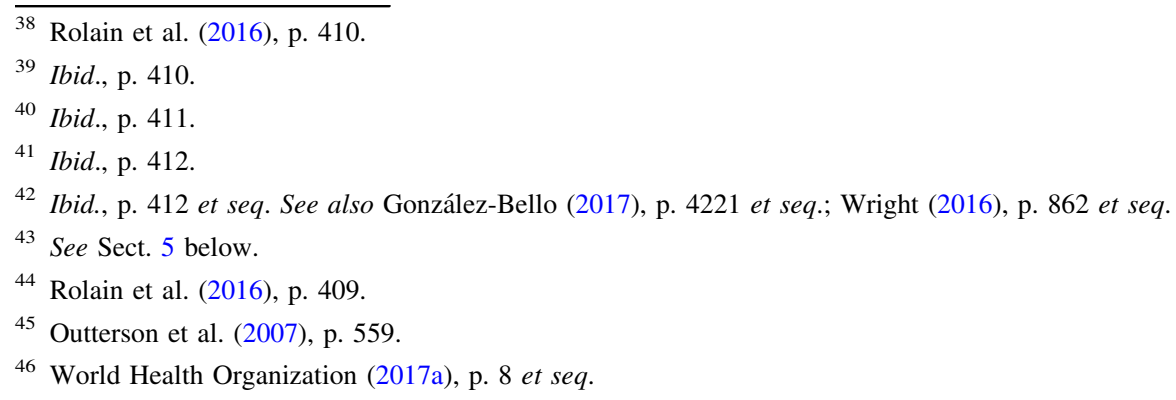


metabolic targets for broad-spectrum antimicrobials ${ }^{47}$ and, therefore, there are major limitations to the invention of new classes of antimicrobials. In addition, parallel factors, such as the difficulty of involving patients with acute infectious diseases in clinical trials, uncertainty regarding diagnoses and variability in the response to antibacterial drug treatment according to the patient's health condition are factors that hinder relevant innovation in this field. ${ }^{48}$ While the evaluation of technical challenges to innovation is also part of a future interdisciplinary research agenda, the moderate growth of innovation in the area in recent years ${ }^{49}$ and the fact that some new antimicrobial classes are appearing in the clinical pipeline of the pharmaceutical industry indicate that, despite technical difficulties, there may still be room for technological development in this field.

From an economic point of view, the literature basically points to three factors that can undermine incentives for innovation in the field of antimicrobials.

Firstly, health policies aimed at reducing the consumption of antimicrobials have been adopted in several countries and regions as a way to curb antimicrobial resistance. ${ }^{50}$ The Swedish Strategic Programme for the Rational Use of Antimicrobial Agents and Surveillance of Resistance (STRAMA) was one of the first initiatives in this regard. By introducing guidelines and making comparative studies as a way of raising awareness among physicians and the general population, the program contributed to a $22 \%$ decrease in the consumption of antibiotics in Sweden. ${ }^{51}$ In the US, the federal government's National Strategy for Combating Antibiotic-Resistant Bacteria in Order to Improve Antibiotic Use, Development and Preservation $^{52}$ and the Centers for Disease Control and Prevention (CDC) ${ }^{53}$ are initiatives that aim to achieve similar goals. The European Commission also seeks to promote the prudent use of antimicrobials through its "A European One Health Action Plan against Antimicrobial Resistance (AMR)", 54 noting that measures to prevent antimicrobial resistance should be coordinated and implemented in all regions of the European Union. ${ }^{55}$ The European Centre for Disease Prevention and Control, ${ }^{56}$ which has as one of its initiatives the European Antibiotic Awareness Day, ${ }^{57}$ pursues objectives of control and surveillance of the use of antimicrobials in Europe. At the international level, the World Health Organization endorsed in 2015 the "Global Action Plan on Antimicrobial Resistance", 58 which has as one of its objectives the optimization of the use of antimicrobial agents worldwide.

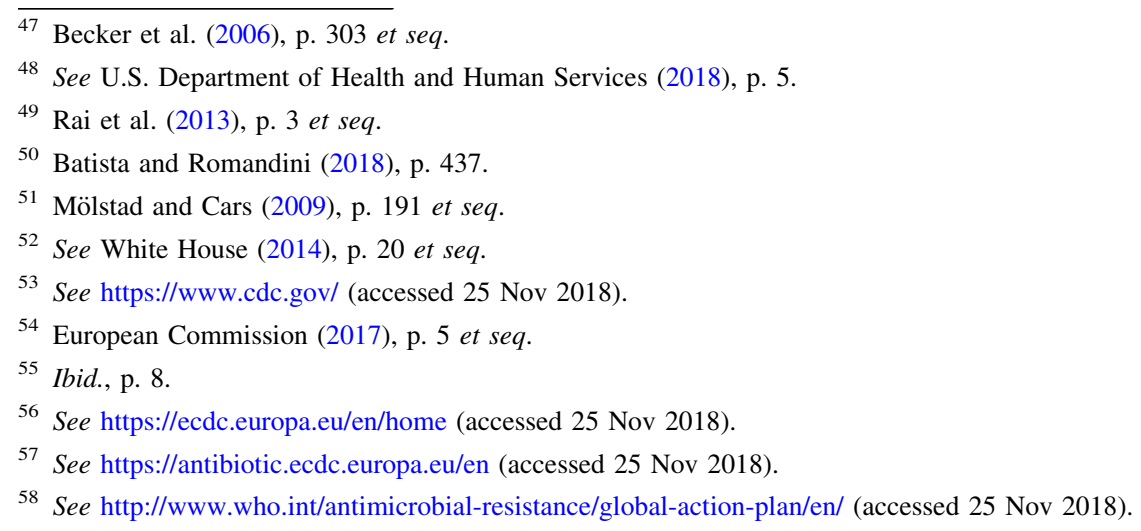


International actions, such as ReAct, ${ }^{59}$ Antibiotic Action ${ }^{60}$ and Transatlantic Task Force on Antimicrobial Resistance (TATFAR), ${ }^{61}$ also contribute to curbing the misuse of antimicrobial agents. The reduction in consumption caused by public policies negatively impacts on the commercialization of antibiotics, which reduces financial returns and makes investments risky.

Secondly, the period of use of antimicrobials in their respective therapies is restricted, especially if compared to other drugs. While treatments for heart diseases, psychiatric disorders and diabetes require the use of the corresponding drugs throughout the life of the patient, antimicrobial-based treatments, besides having only a seasonal high-incidence in the case of some infections, are limited to a short period of time. ${ }^{62}$ Despite the differences in duration of treatment according to the utilized antimicrobial agent, the patient and the infection, antimicrobials are usually prescribed for a period between one and two weeks, and are rarely recommended for more than four weeks. ${ }^{63}$ This reduced time of application of antimicrobials also has negative impacts on commercialization and reduces the prospect of amortization of the investment.

Finally, it is very difficult to predict the period of emergence and the dimension of antimicrobial resistance. ${ }^{64}$ It is possible that resistance - which undermines the effects and thus affects the sales numbers of a given antimicrobial - occurs even before the period of amortization of R\&D costs ${ }^{65}$ and independent of the overuse of antimicrobials. $^{66}$ This reduces business predictability and increases risks for investment and innovation. ${ }^{67}$ Despite the possibility that resistance arises so quickly as to restrict market opportunities during the period in which a new antimicrobial is protected by a patent, ${ }^{68}$ there is no evidence that this is likely to happen, especially in cases of new antimicrobial classes. ${ }^{69}$ However, it must be considered that even marketing on a non-exclusive basis after the expiration of the patent, which may be part of the revenue plans of a company, is made unfeasible by the emergence of resistance. Additionally, uncertainty and unpredictability negatively affect prognoses and market calculations by companies. Ex ante, therefore, the risk of emerging resistance could influence the preferences of private actors in allocating investments in research and development.

It is a fact, anyway, that several large pharmaceutical companies have cut investments in antimicrobials. In July 2018, Novartis announced the end of its

\footnotetext{
59 See https://www.reactgroup.org/ (accessed 25 Nov 2018).

60 See http://antibiotic-action.com/ (accessed 25 Nov 2018).

61 See https://www.cdc.gov/drugresistance/tatfar/index.html (accessed 25 Nov 2018).

62 Lee Ventola (2015), p. 277 et seq.

63 Monteagudo-Chu and Shaeishaa (2017); National Collaborating Centre for Women's and Children's Health (UK) (2012); Leekha et al. (2011), p. 156 et seq.

64 Horowitz and Moehring (2004), p. 577 et seq.

65 Batista and Romandini (2018), p. 437.

66 Schulman (2009), p. 239 et seq.

67 See Schulman (2009), p. 235; Lee Ventola (2015), p. 277 et seq.

68 Schulman (2009), p. 239 et seq.

69 Outterson (2010), p. 639 et seq.
} 
antibacterial and antiviral research programs. ${ }^{70}$ Before that, Bristol-Myers Squibb, AstraZeneca and Eli Lilly had at least partially left this market, ${ }^{71}$ which is now largely occupied by small and medium-sized companies.

At the moment, when antimicrobial resistance is reaching levels of global concern, the current business model for antimicrobials appears to be insufficiently attractive to large pharmaceutical actors.

\section{Incentives Strategies and Policies}

Different strategies have been discussed for the solution of the antimicrobial crisis. Some of them aim to incentivize conservation of antimicrobial effectiveness in order to weaken or retract resistance. This would be possible through lower use of antimicrobial agents in humans and animals. In addition to the abovementioned public awareness, control and surveillance policies, ${ }^{72}$ scholars argue that consumption could be reduced by financial incentives, such as public reimbursement for conservation efforts ${ }^{73}$ and conservation-based market exclusivity. ${ }^{74}$ Further, maintaining high prices for antimicrobials could contribute to more moderate use. This could be achieved through suppression of competition, permanent exclusivity rights, creation of cartels and the creation of a monopsonistic market for antimicrobials. $^{75}$

Additionally, and beyond the scope of mere conservation, some strategies have been discussed and implemented to promote innovation in the field of antimicrobials. Some of them attempt to reconcile the need for innovation with the need for conservation. Before deepening the analysis of the subject of this study, namely the IP-based options, it is important to emphasize that such options are only part of the regulatory possibilities that may possibly contribute to ending the innovation crisis in Europe.

This short section aims to offer a general view of conceivable strategies whose suitability can be analyzed by scholars and lawmakers in the European Union in order to identify appropriate innovation policies. These strategies are commonly categorized into push (3.1) and pull (3.2) mechanisms. ${ }^{76}$ They are at least partially related to public and private initiatives and partnerships implemented at supranational level in order to alleviate the antimicrobial crisis (3.3).

\footnotetext{
${ }^{70}$ Center for Infectious Disease Research and Policy (2018).

71 LeMieux (2018).

72 See Sect. 2.2 above.

73 Outterson et al. (2007), p. 563.

74 Kesselheim and Outterson (2010), p. 1693 et seq.

75 Horowitz and Moehring (2004), p. 578 et seq.

76 For a systematic review of these mechanisms, see Årdal et al. (2018), p. 29 et seq.; Renwick et al. (2017), p. 73; Renwick et al. (2016); Sertkaya et al. (2014); Morel (2011); Sharma and Towse (2010), pp. 7 et seq., 29 et seq.; Morel and Mossialos (2010), p. 1115; Mossialos et al. (2010), pp. 5, 67 et seq.; Webber and Kremer (2001), p. 735.
} 


\subsection{Push Mechanisms}

Push mechanisms seek to reduce barriers to market entry. They primarily target early stages of the research and development process by subsidizing basic and exploratory research and its translation into preclinical and clinical development. As such, push mechanisms reduce the costs and risks incurred by the developer and thereby increase the expected net present value of antimicrobial research and development.

The most discussed push mechanisms are:

(i) support for open-access research and means of knowledge-sharing (e.g. openaccess to scientific databases such as chemical libraries) ${ }^{77}$

(ii) direct research funding through grants or forgivable loans (most likely by public sources, international organizations or private donors, such as venture capitalists, non-profit organizations or philanthropic actors), including conditional grants with strings attached (e.g. commitment to antimicrobial stewardship, equitable and affordable access, contribution to diagnostic development, open-access research etc. $){ }^{78}$

(iii) research fellowships for scientists specializing in antimicrobials; ${ }^{79}$

(iv) tax incentives, such as credits, allowances or deferrals for research and development expenditures, including refundable and tradable tax credits; ${ }^{80}$

(v) product development partnerships (i.e. research and development cooperation, usually in the form of a public-private partnership in which the public partner provides the funding and the private partner conducts the research). ${ }^{81}$

While such push incentives are important elements in the overall strategy to tackle the antimicrobial crisis, it is recognized that incentives are needed along the entire antimicrobial value chain - i.e. basic research, preclinical and clinical development, marketing authorization, and commercialization - to offset the opportunity costs of bringing a new antimicrobial to the market instead of concentrating on more profitable therapeutic areas.

\footnotetext{
${ }_{77}$ For details, see Stern et al. (2017), p. 10; Mossialos et al. (2010), p. 68 et seq., 147; So et al. (2011), p. 92 et seq.

${ }^{78}$ For details, see Årdal et al. (2018), pp. 31 et seq., 54 et seq.; Savic and Årdal (2018), p. 15 et seq.; Stern et al. (2017), pp. 25 et seq., 33 et seq.; O'Neill (2016), p. 49; O'Neill (2015), pp. 15, 23 et seq.; Chorzelski et al. (2015), p. 10; Sertkaya et al. (2014), p. 2 et seq.; Hwang et al. (2014), p. 969; Love (2014), p. 5 et seq.; Kesselheim and Outterson (2010), p. 1692; Mossialos et al. (2010), pp. 71 et seq., 147.

${ }^{79}$ For details, see Stern et al. (2017), p. 27 et seq.; O’Neill (2016), p. 46; Mossialos et al. (2010), pp. 71 and 147.

${ }^{80}$ For details, see Winegarden (2016), p. 17; Clift et al. (2015), p. 4 et seq.; Hwang et al. (2014), p. 968; Sertkaya et al. (2014), p. 2 et seq.; Love (2014), p. 28 et seq.; Sharma and Towse (2010), p. 42; Mossialos et al. (2010), pp. 79 et seq., 147 et seq.

${ }^{81}$ For details, see Chorzelski et al. (2015), p. 11; Spellberg (2014), p. 231; Hwang et al. (2014), p. 968; Sertkaya et al. (2014), p. 2 et seq.; Spellberg et al. (2011), pp. 400, 406 et seq.; Sharma and Towse (2010), p. 42 et seq.
} 


\subsection{Pull Mechanisms}

This is where pull mechanisms come into play. They provide incentives to invest capital and resources into later phases of development, including clinical trials, marketing authorization and commercialization. In contrast to push mechanisms, innovation costs and risks are borne by the developer. But the likelihood of a return on investments for the successful development of a new antimicrobial is increased. There is also no risk of sunk costs, because pull mechanisms only reward successful innovation outputs. But then again, the expected output and the reward may have to be predetermined and the latter must be higher than push funding in both nominal and real terms in order to account for the developer's increased risk exposure.

There are outcome-based pull mechanisms, such as

(i) market entry rewards (i.e. monetary prizes for the development and approval of an antimicrobial that meets a predetermined target product profile and thus targets a specific medical need), ${ }^{82}$ including conditional rewards with strings attached (e.g. commitment to antimicrobial stewardship, equitable and affordable access, contribution to diagnostic development, sales reporting to health authorities, surveillance of resistance levels, restriction to human use, environmental protection etc.) ${ }^{83}$

(ii) advanced market commitments (i.e. an agreement between a donor and a developer to purchase an as yet unavailable antimicrobial that meets specific criteria at a given price up to a fixed amount when and if the product makes it to the market); ${ }^{84}$

(iii) public pricing and distribution of antimicrobials on the basis of

a. patent buyouts (i.e. acquisition of a patent for a new antimicrobial by a funder, most likely the government or an international organization); ${ }^{85}$

b. payer licenses (i.e. exclusive license granted by the patentee); ${ }^{86}$

\footnotetext{
82 For details, see Årdal et al. (2018), pp. 5 et seq. and 37 et seq.; Rex and Outterson (2016), p. 500; O'Neill (2016), p. 54 et seq.; O'Neill (2015), p. 21; Chorzelski et al. (2015), p. 12; Sertkaya et al. (2014), p. 2 et seq.; Morel (2011), p. 6 et seq.; Mossialos et al. (2010), pp. 89 et seq., 149; Morel and Mossialos (2010), p. 1117; for the use of market entry rewards as an alternative to proprietary patent rights, see Love (2014), p. 40 et seq.; Love and Hubbard (2009), p. 155 et seq.; Love and Hubbard (2007), p. 1519.

${ }^{83}$ See Årdal et al. (2018), pp. 8 et seq., 39, 47 et seq., 55, 59 et seq.; Stern et al. (2017), p. 45 et seq.; O'Neill (2016), p. 56.

${ }^{84}$ For details, see Sharma and Towse (2010), pp. 7 et seq., 31 et seq.; Morel (2011), p. 9 et seq.; Mossialos et al. (2010), pp. 95 et seq., 151; Barder et al. (2006), p. 1; Levine et al. (2005); Webber and Kremer (2001), p. 735; Glennerster and Kremer (2000), p. 34.

${ }^{85}$ For details, see Årdal et al. (2018), p. 42 et seq.; Outterson (2014), p. 21 et seq.; Kesselheim and Outterson (2011), p. 163; Morel (2011), p. 8; Mossialos et al. (2010), pp. 91 et seq., 100, 150; Kesselheim and Outterson (2010), p. 1691 et seq.

${ }^{86}$ For details, see Outterson (2014), p. 19 et seq.
} 
(iv) pricing and reimbursement regimes that link the prices paid by public payers and insurance companies to the therapeutic value (public health impact) of the antimicrobial. $^{87}$

In light of the difficulty in marrying the traditional pharmaceutical business model to the specific public health concerns attached to antimicrobials, a common theme across outcome-based pull mechanisms is to de-link - at least partially - the developer's return on investment from price and sales, thereby removing - or at least reducing - its urge to recoup investments through volume-based sales revenues and the concomitant risk of nurturing the emergence and spread of resistance to antimicrobials due to their misuse and overuse. ${ }^{88}$ De-linkage can be implemented through pull mechanisms that entail some sort of payment to the developer, such as market-entry rewards, patent buyouts or payer licenses, ${ }^{89}$ in return for public control over the pricing and distribution of the antimicrobial.

Another category of pull mechanisms comprises legal and regulatory measures aimed at indirectly increasing the developer's return on investment, but without interfering with the patent system's market-based pricing and distribution mechanism, such as

(i) fast track programs aimed at accelerating regulatory approval to allow antimicrobials with significant therapeutic value to reach the market faster, such as

(a) accelerated assessment (or priority review),

(b) conditional marketing authorization (or accelerated approval);

(ii) priority review vouchers (i.e. vouchers granted for the development and approval of determined priority drugs that can be redeemed to expedite review of another medicine that would not normally qualify for priority review);

(iii) longer exclusivities for patents, supplementary protection certificates and clinical data; $;^{90}$

(iv) tax credits for marketing expenditures, on antimicrobial sales, or for sales of antimicrobials to specific institutions (e.g. non-profit and international organizations) $;^{91}$

(v) liability limitations and waivers for developers against claims in the event of injury or death caused by certain antimicrobials; ${ }^{92}$

\footnotetext{
${ }^{87}$ For details, see Kesselheim and Outterson (2011), p. 101; Spellberg et al. (2011), p. 408; Morel (2011), p. 17 et seq.; Kesselheim and Outterson (2010), p. 1693; Mossialos et al. (2010), pp. 121 et seq., 153 et seq.; Outterson (2010), p. 645 et seq.

88 See Årdal et al. (2018), p. 40 et seq.; Rex and Outterson (2016), p. 500; Clift et al. (2015), p. 1 et seq.; Jacznska et al. (2015); Outterson (2014), p. 17 et seq.; Outterson et al. (2011); Kesselheim and Outterson (2010), p. 1693.

89 See Outterson (2014), p. 18 et seq.

90 See Sect. 4.1 below; further reading: Winegarden (2016), p. 14 et seq.; Sinha and Kesselheim (2016), p. 6449; Sertkaya et al. (2014), p. 2 et seq.; Sharma and Towse (2010), pp. 7 et seq., 38 et seq.; Mossialos et al. (2010), pp. 106 et seq., 154 et seq.; Kesselheim and Outterson (2010), p. 1693; Kesselheim and Outterson (2011), p. 128 et seq.; Schulman (2009), p. 221; Sonderholm (2009), p. 240; Outterson et al. (2007), p. 559; Outterson (2005), p. 102 et seq.

91 For details, see Mossialos et al. (2010), pp. 79 et seq., 147 et seq.; Webber and Kremer (2001), p. 735.

92 For details, see Mossialos et al. (2010), p. 126 et seq.
} 
(vi) exemptions from competition rules to allow developers of competing antimicrobials to collude in order to prevent the spread of antimicrobial resistance. $^{93}$

There are also hybrid approaches comprising push and pull elements, such as the proposal to establish an options market for antimicrobials, which provides for the possibility to conclude an agreement with the developer of an as yet unavailable antimicrobial that gives the option holder the right to purchase a specified amount of that antimicrobial at a specified (discounted) price and date when and if the product makes it to the market (the earlier in the product development cycle the call option is purchased, the cheaper it will obviously be). ${ }^{94}$ Another hybrid approach would be a special designation status for antimicrobials.

\subsection{Joint Initiatives}

In response to the supranational nature of the antimicrobial crisis, there has been a proliferation of public and private initiatives and partnerships over the past decade. Governments, international organizations, non-governmental organizations, academia and industry have joined forces to fund, coordinate and support sustainable innovation through initiatives such as the Joint Programming Initiative on Antimicrobial Resistance (JPIAMR), ${ }^{95}$ the Transatlantic Task Force on Antimicrobial Resistance (TATFAR), ${ }^{96}$ the Global Antibiotic Research and Development Partnership (GARDP), ${ }^{97}$ the Innovative Medicines Initiative's (IMI) New Drugs 4 Bad Bugs (ND4BB) program, ${ }^{98}$ the European and Developing Countries Clinical Trials Partnership (EDCTP), ${ }^{99}$ the InnovFin Infectious Diseases (InnovFin ID) program, ${ }^{100}$ the Combating Antibiotic Resistant Bacteria Biopharmaceutical

\footnotetext{
93 Ibid., p. 127.

94 See Brogan and Mossialos (2016), p. 167; Brogan and Mossialos (2013), p. 9; Mossialos et al. (2010), pp. 129 et seq., 157 et seq.; Brogan and Mossialos (2006), p. 641.

95 JPIAMR was established in 2011 by 15 European countries with the support of the European Commission and now comprises 26 countries globally.

96 TATFAR was established in 2009 as a partnership between the US and the EU (see 2009 EU-US Summit Declaration of 3 November 2009) and was expanded in 2015 to include Canada and Norway.

97 GARDP was established in 2016 as a joint initiative by the Drugs for Neglected Diseases Initiative (DNDi), a non-profit organization, and the World Health Organization (WHO).

98 IMI is a public-private partnership between the EU and the European Federation of Pharmaceutical Industries and Associations (EFPIA). As part of the ND4BB program, the IMI funded the DRIVE-AB think tank, a consortium of 16 public-sector partners and seven pharmaceutical companies.

99 EDCTP was set up in 2003 as a public-private partnership between 14 European and 16 African countries, and the EU. It is supported under Horizon 2020, the EU's Framework Programme for Research and Innovation.

100 InnovFin ID was launched by the European Commission and the European Investment Bank (EIB) in 2015 under Horizon 2020 to provide financial products ranging from standard debt to equity-type financing.
} 
Accelerator (CARB-X), ${ }^{101}$ the recently launched Global Antimicrobial Resistance Research and Development Hub (Global AMR R\&D Hub), ${ }^{102}$ and - not to forget the individual projects funded by the EU's Directorate-General for Research and Innovation. ${ }^{103}$

While all of these initiatives seek to overcome the scientific, economic and regulatory challenges that are hampering the development of new antimicrobials, most of them focus on push mechanisms, primarily in early research and development phases (i.e. basic research and preclinical trials). Only very few programs have included pull mechanisms in their agenda. ${ }^{104}$ As a result, there is an imbalance as regards the stages in the product development cycle and, consequently, the type of companies (startups, small caps, mid caps, large caps) that benefit most from the abovementioned joint ventures and initiatives.

\section{IP-Based Incentives}

The US literature has dealt intensively with the question whether and what changes to the IP system could foster the development and conservation of antimicrobials more effectively. ${ }^{105}$ Two approaches have been considered: granting longer exclusivities for antimicrobial-related innovation and granting transferable exclusivities in consequence of antimicrobial-related innovation.

The analysis of the feasibility of these two approaches in the context of the European Union (EU) faces a preliminary institutional issue. This issue is whether such approaches should be considered at the EU level, and - if this were the case whether the measures adopted should have mandatory character for the Member States. There are practical and policy reasons for answering both questions in the affirmative.

Firstly, the instruments available to convey market and IP exclusivities in the EU are currently governed by three sources of law: Union legislation, multilateral agreements and national law. The EU lawmakers can amend EU law and coordinate changes to the applicable multilateral or national law. By contrast, Member States cannot directly amend or extend legal protection granted under instruments of EU law, since the relevant sources of law - such as the SPC Regulation ${ }^{106}$ - are exhaustive. Furthermore, they can only amend the European Patent Convention

\footnotetext{
101 CARB-X is a non-profit public-private partnership launched in 2016 by two divisions of the US Department of Health and Human Services (HHS): the Biomedical Advanced Research and Development Authority (BARDA) and the National Institute of Allergy and Infectious Diseases (NIAID).

102 The Global AMR R\&D Hub was launched in 2018 as a G20 initiative.

103 For a comparative review of major initiatives, see Simpkin et al. (2017), p. 1087; Renwick et al. (2016), p. 31 et seq.; for further national initiatives, see pp. 41 et seq., 85; Hoffman et al. (2015), p. 867.

104 See Renwick and Mossialos (2018), p. 889; Simpkin et al. (2017), p. 1093; Renwick et al. (2016), pp. 2, 55 et seq.

105 Kades (2005), p. 652 et seq.; Schulman (2009), p. 221 et seq.; Outterson et al. (2007), p. 559 et seq.; Spellberg et al. (2007), pp. 169 et seq.; Outterson (2005), p. 119 et seq.

106 Regulation (EC) No. 469/2009 of the European Parliament and of the Council of 6 May 2009 concerning the supplementary protection certificate for medicinal products [2009] OJ L 152/1.
} 
$(\text { EPC })^{107}$ with a higher burden unless such amendments are determined by Union law. 108

Secondly, the effectiveness of an additional incentive depends on the size of the market to which it applies. ${ }^{109}$

Thirdly, any additional exclusivity has benefits that can potentially occur and costs that are likely to arise. The benefits may accrue to any company, wherever located, that invests and applies for the additional protection, and to any consumer, wherever located, who has access to products incorporating the innovation created because of the additional incentive. ${ }^{110}$ The costs are borne mostly by parties - users, health agencies or competitors of the exclusivity holder - that are situated in the market to which the additional protection applies. ${ }^{111}$ This creates an incentive for EU Member States to refrain from unilaterally granting longer or broader protection to pharmaceutical innovators.

Finally, independent national initiatives may lead to a division of the single market and could test the boundaries of primary Union law. For these reasons, any reform of the IP-based incentive available for antimicrobials should be taken at the EU level and be mandatory for EU Member States.

\subsection{Longer Exclusivities}

A first IP-based option to create stronger incentives for antimicrobials innovation is to provide for longer exclusivities. ${ }^{112}$ Under this approach, an entity that has developed an active substance for an antimicrobial indication would enjoy a longerlasting shield against generic competition than would otherwise be possible under the legislation in force. An example for this approach is offered by the Generating Antibiotic Incentives Now Act (hereinafter GAIN Act) signed into law by President Obama as part of the Food and Drug Administration Safety and Innovation Act in 2012. ${ }^{113}$ The act provides for an extension of five years for any data exclusivity period granted under the applicable US statutory rules ${ }^{114}$ for a drug where the latter

107 Convention on the Grant of European Patents (European Patent Convention) of 5 October 1973 as revised by the Act revising Article 63 EPC of 17 December 1991 and the Act revising the EPC of 29 November 2000 [2001] OJ EPO, Special edition No. 4, p. 55.

108 Under Art. 33(1)(b) EPC, the Administrative Council is competent to amend Parts II to VIII and Part $\mathrm{X}$ of the EPC to bring them into line with Union legislation concerning patents. While unanimity is required, such provision allows the Member States to implement Union law without resorting to a revision of the treaty, which would require a burdensome ratification of all Contracting States.

109 Sharma and Towse (2010), p. 45.

110 Romandini (2016), p. 180 et seq.

111 Ibid.

112 Horowitz and Moehring (2004), p. 575 et seq.; see discussion in Höjgård (2012); Outterson et al. (2007), p. 559 et seq.

113 See Public Law 112-144 112th Congress. (9 July 2012). Available at http://www.gpo.gov/fdsys/pkg/ PLAW-112publ144/pdf/PLAW-112publ144.pdf; see further Forsyth (2013), p. 6 et seq.; US Department of Health and Human Services (2018), p. 5 et seq.

114 An exclusivity granted under the GAIN Act can extend the exclusivity provided for new chemical entity exclusivity (five years) under sections 505(c)(3)(E)(ii) and 505(j)(5)(F)(ii) of the Federal Food, Drug, and Cosmetic Act; the exclusivity for the results of new clinical trials according to sections 505(c)(3)(E)(iii) and (iv), and 505(j)(5)(F)(iii) and (iv) of the Federal Food, Drug, and Cosmetic Act; and the exclusivities for 
has been qualified by the Secretary of Health and Human Services - upon request of the manufacturer or sponsor of the drug concerned - as an "infectious disease product". ${ }^{115}$ The designation can also be requested for and granted to products including active moieties previously authorized by the FDA. ${ }^{116}$ As a consequence, the reward is not tailored to privilege and fosters research in new chemical entities. The intended beneficiary of the legislation is the holder of the market approval granted for the antimicrobial product and of a related statutory exclusivity that is eligible for an extension under the GAIN Act.

\subsubsection{EU Perspective}

From an EU perspective, EU lawmakers have several means at their disposal to implement an approach such as the one underlying the GAIN Act. Indeed, the current intellectual property system in the European Union applies without exception to antimicrobial products. Inventions that concern a new substance with antimicrobial properties, the use of a known substance for an antimicrobial purpose, a combination including known antimicrobials, or a manufacturing process for preparing an antimicrobial, are patentable, provided that the general requirements laid down in Arts. 54-57 EPC or in equivalent domestic legislation are met. ${ }^{117} \mathrm{~A}$ patent granted for an active substance, which is authorized for an antimicrobial indication, its application as an antimicrobial or a process for its manufacture may in turn be designated as a basic patent for the purpose of granting a supplementary protection certificate. ${ }^{118}$ Clinical trial data generated for the purpose of obtaining marketing authorization for an antimicrobial may also be the subject of legal protection under Art. 10(1) Dir. 2001/83/EC. ${ }^{119}$ Consequently, by implementing the option of granting longer exclusivities for antimicrobial products, one may consider: ${ }^{120}$

(i) patents with a term longer than 20 years (4.1.2);

(ii) supplementary protection certificates (SPCs) with a duration longer than that resulting from Art. 13 Regulation (EC) No 469/2009 of the European

Footnote 114 continued

products that are granted orphan drug status pursuant to section 527 of the Federal Food, Drug, and Cosmetic Act; see US Department of Health and Human Services (2018), p. 10.

115 The expression "qualified infectious disease product" means "an antibacterial or antifungal drug for human use intended to treat serious or life-threatening infections including those caused by an antibacterial or antifungal resistant pathogen, including novel or emerging infectious pathogens; or (2) qualifying pathogens listed by the Secretary under subsection (f)"; see §505E(g) of the Federal Food, Drug, and Cosmetic Act.

116 US Department of Health and Human Services (2018), p. 8.

117 Sundberg (2016), p. 35.

118 See Art. 1(c) Regulation (EC) No 469/2009 of the European Parliament and of the Council of 6 May 2009 concerning the supplementary protection certificate for medicinal products [2009] OJ L 152/1 (Reg. 469/2009).

119 Directive 2001/83/EC of the European Parliament and of the Council of 6 November 2001 on the Community code relating to medicinal products for human use [2001] OJ L 311/67.

120 See also analysis by Sundberg (2016), p. 36 et seq. 
Parliament and of the Council of 6 May 2009 concerning the supplementary protection certificate for medicinal products (hereinafter Reg. 469/2009) (4.1.3); or

(iii) data exclusivity with a longer duration than that provided under the legislation in force or an equivalent sui generis right (4.1.4).

As far as international or primary Union law is concerned, there is no obstacle that would prevent the EU lawmakers from implementing one or more of these options.

Regarding patents, the Agreement on Trade-Related Aspects of Intellectual Property Rights (hereinafter TRIPS) ${ }^{121}$ does not mandate that protection be limited to 20 years. Article 33 TRIPS only establishes a minimum standard; furthermore, although the prohibition of discrimination under Art. 27(1) TRIPS admittedly applies to the rights granted under Art. 28 TRIPS, their exceptions (Arts. 30-31 TRIPS) and their term (Art. 33 TRIPS), it does not prevent differential treatment where objective differences exist. ${ }^{122}$

Whether SPCs fall under the scope of TRIPS as a form of extended patent protection is a controversial matter. This question, however, is not decisive for assessing the compliance with international law of prospective legislation to provide certificates with a longer duration where the product consists of an active ingredient authorized for an antimicrobial use. Arguments justifying a differential treatment for antimicrobial innovation in patent law would apply to SPC legislation as well.

Concerning data exclusivity, Art. 39 TRIPS does not mandate a specific and mandatory term of protection. ${ }^{123}$ Furthermore, TRIPS does not contemplate a general prohibition of discrimination, since that laid down in Art. 27(1) TRIPS is limited to patents. One could argue, however, that under primary union law a general principle of equal treatment applies ${ }^{124}$ and that the latter would prevent EU lawmakers from creating differential terms of exclusivity under Art. 10(1) Dir. 2001/83/EC for new chemical entities depending upon the medical indication to which the marketing authorization (MA) refers. But again, even in such a case, the reasons that justify longer patent terms would apply to regulatory exclusivities as well.

\subsubsection{Patents}

Patents with a term longer than 20 years have the potential of creating ex ante a stronger incentive for investing in technical fields for which the extended protection is available. Such incentive would not be subject to any condition other than disclosing a patentable invention concerning antimicrobials.

If the policy choice is that only research in new active ingredients with antimicrobial effect should be privileged, the category of patents eligible for an

\footnotetext{
121 Agreement on Trade-Related Aspects of Intellectual Property Rights, 15 April 1994, 1869 U.N.T.S. 299.

122 Grosse Ruse-Khan and Romandini (2017), p. 9 et seq.

123 See de Carvalho (2010), marginal note 39.302.

124 On equal treatment as a general principle of Union law, see Case-280/93 Germany v. Council [1994] EU:C:1994:367, para. 67; Zuleeg (1992), p. 473 et seq.
} 
extended term should then be limited accordingly. In such a case, the longer term should only be granted to patent applications that disclose a new substance with antimicrobial properties, as well as patent applications that disclose the first antimicrobial indication of a known substance.

A way to implement this option could be to create a general rule according to which a substance for which a use in a method indicated in Art. 53(c) EPC has been disclosed, and where such use for the first time consists in treating a microbial infection, can benefit from protection longer than 20 years. If a piece of prior art discloses or makes obvious the use of the substance(s) concerned for an antimicrobial indication, this should prevent the EPO from granting a patent with an extended term, even if the invention consists in a further antimicrobial indication that is novel and inventive. In this case, only a patent with an ordinary term should be available.

Granting patents with a longer term than the 20-year term provided under Art. 63 EPC to foster antimicrobial research also presents shortcomings and raises operative issues. First, the patentability of a compound says little about its therapeutic value. ${ }^{125}$ Second, the grant of a patent would not reward the effective development of an antimicrobial, but only the disclosure of a compound that can in principle be used for that purpose. Third, as a related point, it would not be easy to select the patents that would be suitable candidates for the extended term if, based on the antimicrobial relevance of the innovation, lawmakers intend to make any qualitative distinctions between inventions that are patentable but eligible only for a patent with an ordinary term and inventions that are both patentable and eligible for a patent with a longer term. Any examination of the subject matter would be a challenge for the patent offices. They could not rely on any data or assessment provided by the health agencies, who years later would eventually examine the antimicrobial agent covered by the patent, after the application for marketing authorization has been filed and the decision over the patent application has been made. Fourth, the incentive would be subject to an intrinsic limitation which applies to the patent system $^{126}$ as such: it would not foster investment in unpatentable products and indications.

\subsubsection{Supplementary Protection Certificates (SPCs)}

A valid supplementary protection certificate issued under Reg. 469/2009 requires the existence of both a patent and a marketing authorization covering the product. ${ }^{127}$ The product eligible for a certificate may be an active ingredient or a combination of active ingredients. ${ }^{128}$ Where marketing authorization has been granted for a medicinal product for an antimicrobial indication, the lawmakers could provide that the certificate issued for the active substance(s) covered by such marketing

\footnotetext{
125 Roin (2009), pp. 536-539.

126 Ibid., p. 529 et seq.

127 Art. 3(a) and (b) Reg. 469/2009.

128 Art. 1(b) Reg. 469/2009.
} 
authorization should benefit from a longer term of protection than the duration resulting from the algorithm laid down in Art. 13 Reg. 469/2009.

If EU lawmakers intended to use the SPC as an instrument for rewarding the development of a marketable antimicrobial and to limit the reward to new active substances not previously authorized as medicinal products, however, the legislation in force would require some adaptations.

On the one hand, a reform creating SPCs with an extended term should require that the patentee also be the holder of the marketing authorization submitted in support of the application for a certificate, in order to benefit from a certificate with an extended term. The provision of the latter should only accrue to a patentee that has contributed to developing a marketable product. ${ }^{129}$ If the marketing authorization and the designated basic patent are in different hands, an agency relationship between the patent owner and the marketing authorization holder should exist. US law and practice can provide a model for introducing such limitation to the SPC entitlement. ${ }^{130}$ On the other hand, if only the development of an antimicrobial agent with a new mode of action is to be fostered, ${ }^{131}$ the eligibility for a certificate with longer duration should be limited to new active substances. To this purpose, the issue of a certificate for derivatives of already authorized substances should only be admitted if they are qualified as new active substances in the marketing authorization submitted in support of the SPC application for a certificate. New combinations, formulations or indications of known active ingredients should not benefit from the extended protection.

Whether the considered limitations to the eligibility of a product for the certificate with longer term are necessary or opportune, however, requires further analysis. Recent literature highlights the importance of incremental innovation aimed at making old antibiotics effective again. ${ }^{132}$ Such innovation consists mostly in the combination of a new adjuvant and an old active substance. ${ }^{133}$ Also, nanotechnology, for instance the conjugation of established antimicrobials onto nanoparticles, is considered to be a relevant approach. ${ }^{134}$ At the moment, these innovations are not eligible for a certificate under SPC legislation. For instance, a combination comprising an adjuvant and an active ingredient is not a combination of active ingredients within the meaning of Art. 1(b) Reg. 469/2009. ${ }^{135}$ If the active ingredient concerned was previously authorized, the relevant marketing authorization granted for a medicinal product that employs the new adjuvant together with the old active ingredient will not satisfy Art. 3(d) Reg. 469/2009. If such active ingredient was already granted a certificate, the relevant SPC application will not comply with Art. 3(c) Reg. 469/2009. In order to accommodate such adjuvantrelated innovations within the SPC regime, it would be necessary to amend the

\footnotetext{
${ }^{129}$ See on this issue Romandini (2018a), p. 21 et seq.; Romandini (2018b), pp. 260 et seq.

130 Ibid., p. 35 et seq.

131 The possible need of qualified innovation is addressed in Sect. 2.1 above.

${ }^{132}$ See Sect. 2.1 above.

133 González-Bello (2017), p. 4221 et seq., Wright (2016), p. 862 et seq.

134 See Kumar et al. (2018).

135 CJEU Case C-210/13 GlaxoSmithKline Biologicals [2013] EU:C:2013:762, para. 35.
} 
notion of a product under Art. 1(b) Reg. 469/2009. The latter should be extended to cover combinations of an active ingredient with a substance(s) that has no pharmacological action on its own. Such amendment would significantly alter the original scheme of the SPC legislation. As a consequence, it should then be limited to the field of antimicrobial agents.

As for the mechanics of the extended term of protection for antimicrobials, there are different ways to implement it. Under Art. 13(1) Reg. 469/2009

the certificate shall take effect at the end of the lawful term of the basic patent for a period equal to the period which elapsed between the date on which the application for a basic patent was lodged and the date of the first authorization to place the product on the market in the Community, reduced by a period of five years.

According to Art. 13(2) Reg. 469/2009 the duration may not exceed five years. One could cancel the five-year cap under Art. 13(2) and exclude the five-year reduction pursuant to Art. 13(1) Reg. 469/2009. But it is possible, and likely necessary, to provide for even longer terms that take into account that even after the grant of a marketing authorization the exploitation of a new antimicrobial is usually delayed because of conservation programs. But the length of the extension is, of course, a delicate issue that requires ad hoc analysis. It also depends on the purposes of the legislation, whether it should only foster the development of a new antimicrobial, or also its conservation.

The grant of a certificate with an extended term has one clear limitation shared with the grant of longer patent exclusivities: compounds that are not patentable or that were not patented for an antimicrobial use would not benefit from the incentive.

\subsubsection{Data Exclusivity}

In order for an active ingredient to benefit from an (independent) period of regulatory data exclusivity, it is necessary and sufficient that it has been granted a marketing authorization and the status of a new active substance. ${ }^{136}$ It does not matter whether the active ingredient, its manufacturing process or its use as an antimicrobial agent is patented or patentable. This is a significant advantage of data exclusivity with respect to patent law in fostering pharmaceutical innovation. The protection granted is not dependent on a value judgment such as that based on the inventive step and is not exposed to an invalidity claim based on prior art generated by the research activity of the patentee itself. ${ }^{137}$

At the same time, regulatory exclusivities also have some shortcomings with respect to patent protection. Ex ante, they offer a weaker incentive than patents because they are only granted after a substance has successfully been selected as a clinical candidate and tested for a therapeutic use. Further, they confer legally weaker protection, since they do not prevent a competitor from bringing a product to

\footnotetext{
136 Article 10(1) of Directive 2001/83 as amended by Directive 2004/27/EC of the European Parliament and of the Council of 31 March 2004 amending Directive 2001/83/EC on the Community code relating to medicinal products for human use (OJ L 136, 30 April 2004, pp. 34-57), and Art. 14(11) of Regulation 2004/726.

137 Cook (2016), marginal notes 17.10-17.12, pp. 534-535.
} 
the market with the same composition if the competitor is willing to bear the costs necessary to prove the safety and efficacy of a bioequivalent medicinal product and to generate the data required for supporting a stand-alone application filed under Art. 8(3) Dir. 2001/83/EC. Therefore, the effectiveness of data exclusivity protection depends on the size of investments and the complexity of the regulatory work needed to obtain a second marketing authorization for a medicinal product comprising the same active substance(s) without relying on the data submitted from the first innovator.

Finally, market exclusivity is shorter than the protection resulting from the patent and an associated SPC, unless the marketing authorization was granted in the last five years before the expiration date of the basic patent. ${ }^{138}$

However, adaptations to the legal framework can cure these apparent weaknesses and culminate in the creation of a sui generis right with specific features designed to address the antimicrobial crisis, such as:

(i) a period of protection longer than the current 8-2-1 mechanism provided under Art. 10(1) Dir. 2001/83/EC;

(ii) a jus excludendi alios covering products that include the same or similar active substance and are effective even when the competitor files a standalone application under Art. 8(3) or Art. 10(b) Dir. 2001/83/EC; and

(iii) a scope of protection extended to any antimicrobial use of the substance as a medicinal product.

\subsubsection{Assessment}

It is assumed in the literature that a rational patentee has an interest in overmarketing a patented antimicrobial as the end of the patent term approaches ("patent holder waste theory") and in keeping the antimicrobial effective before that critical phase. ${ }^{139}$ If these assumptions are accurate, longer exclusivities would have two effects:

(i) they would extend the period within which a rational patent holder has reasons to avoid overuse of the antimicrobial product; and

(ii) they would postpone the critical phase where a patentee has an interest in maximizing sales and revenues.

Therefore, from the perspective of fostering conservation, one may assume that the longer the term, the longer the period is in which product stewardship is fostered. ${ }^{140}$ In a theoretical setting, timely unlimited exclusivity would apparently be able to align private and public interests in maintaining the effectiveness of an IP-protected antimicrobial. ${ }^{141}$ However, such assumptions (including the ability of

\footnotetext{
138 Broes et al. (2016), p. 24.

139 See Horowitz and Moehring (2004), p. 578; Kades (2005), p. 651 et seq.

140 Ibid. Longer exclusivities would also delay generic competition, which would possibly lead to an increase in the consumption of the antimicrobial concerned. See again Horowitz and Moehring (2004), pp. $577-578$.

141 Kades (2005), p. 652.
} 
longer patents to promote conservation) are disputed by scholars. ${ }^{142}$ On the one hand, resistance against a class of compounds sharing the same principle of action and addressing the same target is possible even without overuse (or even use) of the antimicrobials concerned. This could induce the patentee to exploit immediately and on a large scale the antimicrobial which was granted a marketing authorization. On the other hand, the patent holders (or their licensees) could for economic reasons be compelled to prioritize short-term financial rewards rather than maintain long-term commercial options. ${ }^{143}$

With respect to the goal of encouraging the development of antimicrobials, the analysis is even more complex. As mentioned above, ${ }^{144}$ there are four factors that account for the lack of interest of pharmaceutical companies in the antimicrobial market, namely:

(i) uncertainty about the emergence and dimensions of resistance;

(ii) comparably low income due to the more limited use of antimicrobials in relation to drugs aimed at treating lifestyle diseases;

(iii) national health policies preventing the exploitation of new antimicrobials as long as old active ingredients have not turned out to be ineffective; and

(iv) technical difficulties in finding new antimicrobials.

If we consider the threat of resistance as a factor discouraging ex ante pharmaceutical companies from engaging in antimicrobial research, longer exclusivities are unlikely to have any effect in this respect. If the risk of emerging resistance during the patent term influences companies' choice of what type of products to invest in, such influence remains the same regardless of whether the patent has a term of 20,25 or 30 years.

Regarding the technical challenge of finding new antimicrobials, longer terms of exclusivities cannot directly change anything in this respect either. However, they can make inventions that overcome such technical challenges more profitable.

With respect to the policy of keeping new antimicrobials in reserve, longer exclusivities do not have any impact. Indeed, the health policies of the individual Member States remain unaffected by the patent term. The same holds true for the standardized short duration of antibiotic treatment (an average of two weeks). Admittedly, higher aggregate revenue may be obtained through longer terms of protection. However, in order to have a chance of increasing private investment, the extension of exclusivity should be such as to ensure a remuneration of the investment that would at least be comparable with that in other fields, such as lifestyle or chronic diseases. The timing of the promised reward could ex ante also play a role in the decision of a company to direct resources to antimicrobial research. In this respect, patent extensions are faced with the problem that the "projected value of an extension

\footnotetext{
142 See, for instance, Schulman (2009), p. 234 et seq.; Outterson et al. (2007), p. 563.

143 The "patent holder waste" hypothesis itself is subject to controversy in scholarship. The literature points to cases where the marketing of an antimicrobial had apparently intensified when the patent end approached (see Outterson et al. (2007), p. 563); however, only extensive empirical research could confirm whether and to what extent such hypothesis is grounded. See Mossialos et al. (2010), p. 113 with further references; Outterson (2010), 616 et seq. and 627 et seq.

144 See Sect. 2.2 above.
} 
at the time of making an investment decision, the net present value (NPV), is relatively small". ${ }^{145}$ The uncertain future "additional return" ${ }^{146}$ promised by longer exclusivities must be contrasted to the investment needed and the associated risks for drug development. As a consequence, even if significantly longer protection were granted for the whole EU market, it is unclear whether it would be effective in bringing large pharmaceutical innovators back to antimicrobial research. This assessment finds some backing in the experience in the US with the GAIN Act. ${ }^{147}$ In assessing the effectiveness of the legislation, the US Food and Drug Administration (hereinafter FDA $)^{148}$ and the literature ${ }^{149}$ have acknowledged positive effects. The number of antimicrobial approvals during the six years after the GAIN Act came into force was higher than the number of approvals in the six years before. It is possible that two main measures in the GAIN Act - faster FDA review and longer exclusivities for antimicrobials - may have contributed to this development. However, according to the FDA Report submitted in 2018 to the US Congress with data concerning the "qualified infectious diseases products", ${ }^{150}$ the antibiotics pipeline remains "fragile" ${ }^{151}$ and "additional efforts" are needed. ${ }^{152}$

\subsection{Transferable Exclusivity Extensions}

The uncertainty surrounding the effectiveness of traditional IP protection in the field of antimicrobials, even with a longer term, had induced policymakers and literature in the US even before the enactment of the GAIN Act to consider alternative approaches, such as the creation of a "wild card" or "transferable" extension of exclusivity. ${ }^{153}$

The function of a "wild card" or a "transferable" exclusivity extension is to reward the development of an antimicrobial with the extension of marketing exclusivity related to another product. ${ }^{154}$ In its widest model, such extension can apply to any

(i) existing or prospective exclusivity rights owned by the antimicrobial developer itself; and

(ii) existing or prospective exclusivity rights owned by a third unrelated entity that has acquired the transferable extension from the antimicrobial developer or its successor in title.

\footnotetext{
145 See Harris et al. (2013), p. 67; see also pp. 88-89 (with specific reference to the Australian market).

146 Ibid., p. 67.

147 See Sect. 4.1 above; Forsyth (2013), p. 6 et seq.

148 US Department of Health and Human Services (2018), p. 7 et seq.

${ }^{149}$ Sfeir (2018), p. 1 et seq.

${ }^{150}$ US Department of Health and Human Services (2018), p. 7.

${ }^{151}$ Ibid.

152 Ibid., p. 22.

153 Sonderholm (2009), p. 241; Spellberg et al. (2007), p. 169 et seq.

154 See Sonderholm (2009), p. 240; Spellberg et al. (2007), pp. 169 et seq.; Batista and Romandini (2018), p. 441; Sundberg (2016), p. 50 et seq.
} 
The de-linked feature of the extension ensures that the innovation consisting in a new antibiotic product is compensated by the revenue generated by another potentially more profitable product. Its transferability also enables companies without IP rights in more remunerative products ${ }^{155}$ than antimicrobials to benefit from the reward. ${ }^{156}$

An example of this approach in the field of antibiotics is offered in the ReValuing Anti-Microbial Products Bill H.R. 6294 introduced on 26 June 2018 before the US Congress. ${ }^{157}$ The bipartisan initiative shall establish a 12-month transferable extension to encourage development of "novel therapies targeting serious microbial infections". The transferable exclusivity extension shall be granted where two requirements are met: (i) the antimicrobial agent for which an approval has been requested has been designated - upon request of the sponsor - as a priority antimicrobial product; (ii) the antimicrobial agent has been granted a market approval pursuant to Sec. 505(c) Federal Food, Drug, and Cosmetic Act or Sec. 351(a) Public Health Service Act (concerning biologics). If these requirements are complied with, the Secretary shall award the holder of the approved application a 12-month exclusivity extension "for the sole purpose of conveying such extension in whole or portions to other sponsors or holders to be applied with respect to one or more drugs" ("recipient drug"158). The recipient drug shall be subject to one of the statutory exclusivities listed by the proposed legislation or to a patent in order to benefit from the extended exclusivity period. ${ }^{159}$

The extension is not effective if "the conveyance of an exclusivity extension" is made "later than 4 years prior to the expiration" 160 of the legal protection granted under data exclusivity or patent rules for the recipient drug. In the case of patents, the effect of the extension is not to prolong their term, but to confer a period of exclusivity following their expiry. ${ }^{161}$ During that period, approval of an application for a generic of the recipient drug "may not be made effective by operation of subsection (c)(3) or (j)(5)(B) of section 505" Federal Food, Drug, and Cosmetic Act.

\footnotetext{
155 This aspect is of critical importance for the antimicrobial market considering the significant role of small and medium-sized companies; see Butler et al. (2017), p. 3 et seq.

156 President's Council of Advisors on Science and Technology (2014), p. 40; Mueller-Langer (2013), p. 193. If the exclusivity extension is tradable, its holder can convey it and participate in a portion of the profits earned by sales of the medicine covered by the purchaser's exclusivity. How high this portion will be depends on the bargaining power of the parties, which in turn will be affected by several factors, such as: the number of transferable exclusivities available on the market at the critical date, the impact on the price of the reference drug that biosimilars or generic competition may have, the urgency for the antimicrobial innovator to monetize the transferable extension, and the validity of the latter, i.e. the period of time within which it can validly extend an exclusivity right. See also Outterson et al. (2007), p. 562.

157 H.R. 6294 (Re-Valuing Anti-Microbial Products Act of 2018 - REVAMP Act). Available at https:// www.congress.gov/bill/115th-congress/house-bill/6294/text (accessed 25 Nov 2018).

158 Recipient drug means "a drug approved under section 505" of the Federal Food, Drug, and Cosmetic Act and that received "a conveyed exclusivity extension period"; see the proposed section $530(\mathrm{p})(5)$, H.R. 6294, ibid.

159 See the proposed section 530(a), H.R. 6294, ibid.; see also Karst (2018).

160 See lit. (f) of proposed section 530, ibid.

161 See Karst (2018).
} 
As to the operation of the extension, the period of exclusivity is extended after the holder of an approved application for a priority antimicrobial product has submitted notice to the Secretary of Health and Human Services that the extension was conveyed. In that notice, the holder of the marketing approval shall also identify the antimicrobial product, the recipient drug and the duration of the conveyed exclusivity extension period. The holder of the conveyed exclusivity extension can in turn "sell, exchange, convey or hold" the latter subject to some limitations. ${ }^{162}$

The designation of a priority antimicrobial product and the award of the conveyable extension shall be subject to a number of conditions aimed at fostering conservation and research in antimicrobial products. Inter alia, the antibiotics developer is required to transfer an amount that is equal to five percent of the total value of the consideration received as a result of the conveyance, to agree to take precautions aimed at ensuring "appropriate use" 163 and to submit periodic assessment reports on the conducted stewardship activities. ${ }^{164}$

\subsubsection{EU Perspective}

The US model briefly reported above could be implemented in Europe as far as the data exclusivity period ${ }^{165}$ and supplementary protection certificate (SPC) ${ }^{166}$ are concerned. As to SPCs, lawmakers could establish that the applicant, together with the marketing authorization submitted pursuant to Art. 8(1)(b) Reg. 469/2009 and (if applicable) evidence of a completed pediatric study submitted pursuant to Art. 8(1)(d) Reg. 469/2009, may submit a copy of a transferable extension. The latter shall then be taken into account in calculating the term of the certificate under Art. 13 Reg. 469/2009.

The same principles would apply mutatis mutandis to periods of data exclusivity. Appropriate provisions could ensure that, at a relatively early stage in the procedure for obtaining a marketing authorization, the applicant can also submit a granted or acquired extension. The latter shall then be computed in determining the term of protection for the new active substance or the new indication approved.

In principle, transferable extensions could also be used to extend patent terms. At the European level, it would require an amendment of Art. 63(2) EPC. But such amendment, provided that Union legislation is enacted, could be adopted under the abridged procedure pursuant to Art. 33(1)(b) EPC. However, there are reasons why EU legislators should limit the scope of transferable extensions to SPCs or regulatory data exclusivity. On the one hand, the US system does not contemplate SPCs, but only patent extension subject to the requirements listed in 35 U.S.C. $§ 156$. This may

\footnotetext{
162 See lit. (e) of proposed section 530, ibid.

163 See lit. (e) of proposed section 530, ibid.

164 See lit. (e)(4) of proposed section 530, ibid.

165 See Sect. 4.1 .4 above.

166 See Sect. 4.1.3 above. See also Towse and Kettler (2005), pp. 70-71 et seq.
} 
explain the reference to patents included in H.R. $6294 .{ }^{167}$ On the other hand, providing transferable extensions only to forms of legal protection that require the grant of a marketing authorization for a new active ingredient or combinations of new active ingredients guarantees that in principle only the most valuable innovations are rewarded with a longer period of exclusivity. Furthermore, by limiting the eligibility for the extension only to SPCs granted on the basis of a marketing authorization obtained by the SPC applicant itself, ${ }^{168}$ the legislation would also make sure that the entity that benefits from the longer term of protection and the entity that has invested in developing the "recipient drug" are one and the same. ${ }^{169}$

As to the requirements for granting the transferable exclusivity extensions, the lawmakers have a number of options. In line with Bill H.R. $6294,{ }^{170}$ the minimum condition should be that the applicant has obtained a marketing authorization for a medicinal product with an antimicrobial indication. Furthermore, the lawmakers could require that the marketing authorization concerned was filed under Art. 6 Dir. 2001/83/EC, and in addition that the active ingredient has been granted the status of a new active substance under Art. 3(2) Reg. 726/2004. Finally, the lawmakers could conceive of further limitations to the eligibility in terms of therapeutic indications or mode of action of the active substance(s) comprised in the medicinal product. Whether some or all mentioned conditions should apply is a matter of policy. It depends on what type of innovation the legislature intends to foster and reward.

\subsubsection{Issues}

While EU legislation provides sufficient room for adopting the model of conveyable exclusivity extensions covering an approved antimicrobial within the system of existing IP and regulatory rights, the assessment whether this step should be taken is more complex. The creation of transferable exclusivity extensions is indeed highly controversial.

\subsubsection{Constitutional Concerns A first category of concerns is of a fundamental} nature. It is argued that transferable exclusivity extensions break the relationship between innovation and reward, could unfairly frustrate the legitimate expectations of generics competitors, and finally lead to arbitrary differentiated treatment of antibiotics developers. ${ }^{171}$

The argument based on the link between innovation and reward has legal strength in the US context. Under the so-called patent and copyright clause of the US

\footnotetext{
167 H.R. 6294 (Re-Valuing Anti-Microbial Products Act of 2018 - REVAMP Act). Available at https:// www.congress.gov/bill/115th-congress/house-bill/6294/text (accessed 25 Nov 2018).

168 See on the issue of SPCs requested on the basis of a marketing authorisation obtained by an unrelated third party the analysis by Romandini (2018b), p. 260 et seq.

169 In US law, such precautions are not needed. It is not possible for the patentee to obtain an extension of its patent based on approval obtained by a third unrelated entity. An agency relationship between the holder of the product approval and the owner of the patent is required. See Romandini (2018a), p. 19 with further references.

170 See Sect. 4.2 above.

171 Outterson et al. (2007), p. 562; Nickas (2012), p. 6 et seq; Cars et al. (2008), p. 23.
} 
Constitution, Congress is empowered to grant inventors exclusivity rights in their discoveries and not unrelated subject matter. ${ }^{172}$ However, such a concern appears to be less relevant from the perspective of primary EU law. If the EU lawmakers consider the social value of a specific antimicrobial innovation to be higher than its market value, and intend to close the gap through a transferable extension, there are no limitations to their competence and entitlement to do so in primary law, provided that the legislative initiative is directed to foster the smooth functioning of the single market and prevent a heterogeneous development of national legislation. ${ }^{173}$

The legitimate expectations of market actors, including generics manufacturers, are of course protected under primary EU law. ${ }^{174}$ However, an appropriate design of the mechanism ${ }^{175}$ can mitigate concerns in this regard. For instance, the EU lawmakers could provide - in analogy to the pediatric extension - that:

(i) the transferable exclusivity extension shall apply only to a specific category of rights - for instance SPCs requested after a critical date; and

(ii) a reference to the transferable exclusivity extension and evidence concerning its grant or purchase shall be submitted by filing the application for the certificate.

In this way, any operator could predict in advance, namely within six months after the marketing authorization for a patent-protected active ingredient or combination of active ingredients has been issued, ${ }^{176}$ what the potential and residual term of IP protection may be, and plan accordingly the launch of a generic or a biosimilar of the reference product. Similar precautions are possible with respect to data exclusivity protection. ${ }^{177}$

The concerns related to the possible arbitrary character of the reward conveyed are not without merit. Transferable exclusivity extentions can determine at least two forms of unequal treatment, namely:

(i) among the holders of the exclusivities in abstracto eligible for an extension, since some of them will benefit from the additional term of protection and

\footnotetext{
172 According to Art. 1 Section 8, Clause 8 of the US Constitution, the US Congress shall have the power "to promote the Progress of Science and useful Arts, by securing for limited Times to Authors and Inventors the exclusive Right to their respective Writings and Discoveries". According to Outterson and McDonnell (2016), p. 787, the provision establishes a link between exclusivity and discovery, so that Congress can reward innovation only with IP rights covering that innovation and not another subject matter.

173 See for instance Art. 114 Treaty on the Functioning of the European Union, OJ C 115, 9 May 2008, pp. 94-95.

174 See for instance Case 112/77 Töpfer [1978] ECR 1019, esp. 1032-1033, paras. 18-19.

175 See Outterson and McDonnell (2016), p. 787 et seq.; IFPMA (2018).

176 See Art. 6(1) Reg. 469/2009, according to which the application for a certificate shall be lodged within six months of the date on which the marketing authorization for the product was granted. If the marketing authorization is granted before the basic patent is issued, "the application for a certificate shall be lodged within six months of the date on which the patent is granted"; see Art. 6(2) Reg. 469/2009. In both scenarios, within six months of the grant of the marketing authorization or of the relevant patent, any competitor would know whether a certificate is granted and what (potentially extended) duration it will have.

177 See Sect. 4.1.4 above.
} 
others will not, depending on the acquisition and availability of a wild card; and

(ii) among the holders of transferable extentions themselves, since their reward is linked to the revenues that sales of another product, unrelated to the antimicrobial innovation, can generate. ${ }^{178}$

However, again, it is questionable whether these two critical points would prevent the lawmakers from introducing transferable exclusivity extensions for constitutional reasons. The apparent unequal treatment of the holders of extendable exclusivities would result from the fact that some of them have acquired a transferable extension and some have not. It is based, therefore, on the ability and disposition to pay an adequate price for the conveyable extension. Both are affected by the value of the product that could benefit from an extended protection.

As a reward for antibiotics developers, the latter could present arbitrary differences where the transferable exclusivity extensions have a short term of validity. ${ }^{179}$ For instance, if the owner of a transferable extension only has one year to find a buyer, because after that period the transferable extension expires, the sale of the latter could generate higher or lower revenues depending on whether or not a patent for a blockbuster drug approaches the end of the patent term during that period of time and the owner of the related patent intends to purchase the transferable extension. Differences in the price obtained by the conveyance of the extension could be significant. And they would not be related to the value of the antimicrobial innovation rewarded. However, if the transferable exclusivity remained valid for a longer period of time, for instance 15 years, this would create a secondary market for tradable extensions. Each holder would have more opportunities and time to find an adequate offer. Of course, the longer validity of the transferable exclusivity extensions may reduce their individual market value. But this will also depend on other factors, such as how many transferable extensions the legislature intends to allow, ${ }^{180}$ and under what conditions.

4.2.2.2 Fairness A second line of argument against the creation of transferable exclusivity is based on fairness. The financial burden of rewarding the development of an antibiotic would be borne by an unrelated group of patients, more precisely the patients in need of the drug subject to the extended exclusivity. ${ }^{181}$ At least from a European perspective, the relevance of this argument is questionable.

In most EU countries, health policy ensures that at least lifesaving or lifeimproving pharmaceuticals are covered by publicly funded health insurance

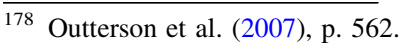

179 By term of validity we do not mean the period for which the protection of exclusivity may be extended by virtue of the transferable extension (6, 12 or 24 months, for instance), but the period within which the latter can still be used or transferred to extend a pre-existing exclusivity. Theoretically, the transferable extension could be issued without an expiration date.

180 Outterson et al. (2007), p. 562.

181 See President's Council of Advisors on Science and Technology (2014), p. 40; Cars et al. (2008), p. 23; Outterson et al. (2007), p. 562.
} 
systems. ${ }^{182}$ Further, antimicrobial treatment is ancillary to a large number of therapies for different diseases, such as chemotherapy or surgical interventions. ${ }^{183}$ The eradication of microbial infections has a general impact on public health. In several cases, there will be an intersection between the consumers of "recipient drugs" and the beneficiaries of antibiotic innovation.

Finally, a cross-funding of pharmaceutical research is immanent in the patent system. ${ }^{184}$ The revenues generated by a specific patented blockbuster are, and must be, far higher than the entire costs of its development and the marginal costs for its manufacture. The revenue from successful products should remunerate past failures and fund future - related or unrelated - research. This was also one of the assumptions on which the decision of EU lawmakers in 1992 to allow a retrospective application of the SPC legislation was based. ${ }^{185}$

4.2.2.3 Efficiency A third reservation against transferable extensions concerns their efficiency. ${ }^{186}$ It is argued that they have the shortcomings of both prizes and patents, without sharing their virtues. ${ }^{187}$ As patents, they determine static inefficiencies. ${ }^{188}$ As prizes, they do not ensure that the reward matches the value of the innovation. ${ }^{189}$

Efficiency arguments are not rebuttable as such. No factual evidence for the operation of wild-card extensions and their impact on health costs is available in the US or elsewhere. ${ }^{190}$ And it is true that the mechanism incorporates significant risks of over-compensation, which can occur in two situations where the transferable exclusivity extension rewards:

(i) the development of an antimicrobial that would have taken place anyway, if driven by the market and/or general applicable incentives; and

(ii) the development of an antimicrobial that would not have taken place or would only have taken place years later, but the societal and economic costs of the additional exclusivity are higher than the societal and therapeutic value of the innovation rewarded.

\footnotetext{
182 See Sonderholm (2009), p. 243 et seq.; Sharma and Towse (2010), p. 37.

183 Outterson (2018).

184 Winegarden (2016), p. 15.

185 See Art. 19(1) Reg. 1768/92. See also European Commission, Explanatory Memorandum to the Proposal for a Council Regulation (EEC), of 11 April 1990, concerning the creation of a supplementary protection certificate for medicinal products (COM(90) 101 final - SYN255), para. 15, and the reference to the "self-financing" nature of pharmaceutical research.

186 Outterson et al. (2007), p. 561; O’Neill (2015), Appendix B, p. 38; Mossialos et al. (2010), p. 115 et seq.

187 Kapczynski (2009), p. 265 et seq. See also Outterson et al. (2007), p. 561; O’Neill (2015), Appendix B, p. 38.

188 Kapczynski (2009), p. 265 et seq.

189 Ibid.

190 See Sect. 5.3.3 below.
} 
Nevertheless, an appropriate design of the system can reduce these risks. ${ }^{191}$ Lawmakers could limit the category of antimicrobial drugs that qualify for a transferable exclusivity extension. On the one hand, they could select a list of priority antimicrobial indications, in order to ensure that medical needs and the scope of incentive align with each other. ${ }^{192}$ Only an antimicrobial targeting of one of these indications should justify the award of an extension. On the other hand, the lawmakers could provide that only marketing authorizations granted for medicinal products that aim at a new target and/or employ a new active substance with a new mode of action would satisfy the requirements for granting an extention.

In order to make the costs of each single extension predictable, one could determine that the extended exclusivity ends either after a specific period of time has expired or after an amount of revenue has been earned, whichever is earlier. ${ }^{193}$ Furthermore, in consideration of the likely limited number of vouchers that would be granted, one could even provide a definition of the term (or the compensation cap) case by case. A determination of the term of the IP granted case by case would be unique in the current landscape of IP exclusivities, but not without precedent in a diachronic perspective. ${ }^{194}$ By contrast, the creation of a revenue cap would be unprecedented. In the European context of different national markets the application of this cap would pose more challenges than in the US market.

The described measures would not nullify the risk of granting compensation that was not causal to the development of the antimicrobial concerned. Such a risk is immanent in the patent system as well. However, even in that factual scenario, the grant of a transferable extension would allow the lawmakers to mandate stewardship programs that would not be feasible without the additional (and optional) reward.

Ultimately, the creation of further incentives for antibiotics research is aimed at improving the relationship between risks and revenue for private companies and investors that decide to enter the field of antimicrobial innovation. As a result of this exercise, any measure that would be effective and improve this balance would shift a part of the risk or a part of the cost from private investors to public funding or institutions.

\footnotetext{
191 See again the analysis by Outterson and McDonnell (2016), p. 784 et seq.

192 Identification of priority pathogens is not simple, since it postulates the existence of established criteria for assessing the health impact of pathogens. However, this did not prevent the WHO from formulating a list of priority pathogens in 2016. See analysis in World Health Organization (2017c). Such studies could also form the basis of legislation providing for extendable exclusivities, where a limitation of the category of the antimicrobials that should be eligible for the reward is intended. See also Schulman (2009), p. 45.

193 See Outterson and McDonnell (2016), p. 788.

194 See, for instance, Section 23 United Kingdom Patents Act 1949 (12, 13 and 14 Geo. 6 c.87). Under the mentioned provision the patentee could apply for an extension on the grounds of inadequate remuneration. The granted extension could not be longer than five years, or ten years in exceptional cases. Within these limits the High Court had the task of determining for what period the patent should be extended according to the individual merit of the invention and all the circumstances of the case. See Aldous et al. (1965), marginal numbers 537-538, p 223.
} 


\subsubsection{Assessment}

If one considers the purpose of fostering conservation, transferable exclusivities are per se a neutral measure. They concern an exclusivity right unrelated to the antimicrobial subject of the reward. They do not affect, reduce or exacerbate reasons for an over-zealous promotion of the antimicrobial during the legal protection from which the latter benefits under patent or regulatory provisions. However, because they guarantee additional revenue generated from conveying the transferable extension and de-linked from the volume of sales of the antimicrobials, they provide the lawmakers with the option of imposing rigorous stewardship programs. ${ }^{195}$ Acceptance of and compliance with the obligations aimed at ensuring appropriate use of antimicrobials could be provided as conditions for granting a transferable exclusivity extension. ${ }^{196}$ Violations of such obligations could be made a reason for its revocation.

As to the purpose of fostering the development of new antibiotics, transferable exclusivities have some arguments in their favor. ${ }^{197}$ First, they have the potential to provide the antibiotics developer with significantly higher revenues than longer patent protection for the antimicrobials. Second, they are effective in de-linking the reward for the antimicrobial development from the volume of antibiotics sales. ${ }^{198}$ Third, they resort to an incentive - data exclusivity or SPC protection for profitable drugs - that is already tested and considered attractive by the industry. ${ }^{199}$ Fourth, their introduction may have significant costs, but does not require direct public funding. ${ }^{200}$ Within the EU, it would help distribution of the burden of the additional incentive among the various Member States, by calibrating the contribution of each national health system to the economic relevance of the specific domestic pharmaceutical market.

However, whether the additional incentive would really be effective in fostering innovation that would not otherwise take place in the EU or anywhere else is a question that legal analysis cannot answer. Developing an antibiotic - including failures - according to some estimates costs from 700 million to 1.1 billion euros. $^{201}$ A transferable extension granted for the EU market could be designed to cover at least a significant portion of these costs. Whether this would be sufficient to win back antibiotics research by large pharmaceutical companies is uncertain. In the field of SPCs, economic literature considers it unlikely that a one-year extension could really prompt a shift in the global preferences of private investors and

\footnotetext{
195 See, for instance, IFPMA (2018); for examples of stewardship programs, see also Årdal et al. (2018), pp. 9, 46 et seq., 62 et seq.

196 Again, Bill H.R. 6294 provides examples of this approach. See lit. (m) of the proposed Sec. 530, H.R. 6294; see Sect. 4.2 above.

197 See the analysis in Sonderholm (2009), p. 241; Sharma and Towse (2010), pp. 7 et seq., 38 et seq.; Mossialos et al. (2010), pp. 106 et seq., 154 et seq.

198 Sonderholm (2009), p. 241.

199 See IFPMA (2018).

200 Sonderholm (2009), p. 241.

201 Renwick et al. (2016), p. 18; O’Neill (2015), p. 21.
} 
pharmaceutical companies. ${ }^{202}$ Similar doubts may be justified with respect to a oneyear transferable extension specifically tailored to antimicrobials. Therefore, a factor that will influence not only the effectiveness of the system, but also the design of the incentive, will be the attitude of other relevant WTO members as well as the ability of EU institutions to export the instrument to other jurisdictions as a feature of future partnerships or free-trade agreements, if they decide to adopt this legal instrument for the EU market. ${ }^{203}$

\section{Research Agenda}

As observed in the previous sections, legal research cannot offer appropriate options for public policies in the field of antimicrobial resistance without the support of other sciences. The coherence and effectiveness of possible IP-based incentives depend on some assumptions and expectations that can only be confirmed - and only in part - by research in other fields, such as biology, epidemiology and economics. A number of diverse questions calls for an interdisciplinary research approach that should both precede and follow the legal assessment of legislative options.

\subsection{Is There an Antimicrobial Crisis?}

Recent contributions call into question the existence of an antimicrobial crisis. Doubts are based on uncertainties regarding microbial performance, resistance evolution and empirical analysis of the extent of resistance. ${ }^{204}$ In addition, the alleged effectiveness of therapies based on the use or revitalization of known antimicrobial drugs contributes to dispelling the idea of absolute necessity for new antimicrobials. $^{205}$ At the same time, there is no consensus on whether there are relevant technical barriers that curb further innovation in the field of antimicrobials. While most literature believes that appropriate incentives can promote innovation in this market, more skeptical authors see innovation in this sector as close to exhaustion because of the absence of new targets. ${ }^{206}$

From the regulatory point of view, it would not be consistent to implement measures that may create high social costs - such as transferable extensions without the certainty that they will be offset by a corresponding increase in welfare. If the crisis is merely apparent or may be solved within the current framework of pull and push incentives, there is no justification for a regulatory intervention. Further, political regulatory efforts could be saved in the absence of relevant perspective innovation. Therefore, the first preliminary question is whether there

\footnotetext{
202 See the assessment of Kyle (2017), p. 31, with respect to the ability of one-year additional patent protection as a consequence of an SPC in determining such "a change in global profits to shift R\&D investment".

203 Sharma and Towse (2010), p. 45.

204 See Sect. 2.1 above.

205 See Sect. 2.1 above.

206 See Sect. 2.2 above.
} 
really is an antimicrobial crisis to be addressed by additional and exceptional measures.

\subsection{What Kind of Innovation is Desired?}

Assuming the existence of a crisis, it is necessary to identify what kind of innovation should be incentivized at the regulatory level. As noted above, ${ }^{207}$ the development of mere intra-class antimicrobial agents may not be sufficient according to some views to curb antimicrobial resistance. Effective solutions could therefore require a higher level of innovation, such as the development of new chemical entities, new mechanisms of action and/or the identification of new targets in the microbial cells or structures. By contrast, if known active ingredients could be made effective again - for instance, within the context of combination therapy or through the development of new adjuvants - then the system of incentives should be designed accordingly. This question is primarily of an epidemiological and pharmacological nature.

\subsection{Economic Studies for Implementation of IP-Based Incentives}

The implementation of economic incentives for the development of new antimicrobial drugs creates social costs that must be compensated by a corresponding increase in welfare. This will only be the case if public policies encourage relevant and effective innovation, and not just any innovation. As noted above, ${ }^{208}$ exclusivity extensions and transferability may provide important economic incentives for R\&D improvement in the field of antimicrobials. However, merely theoretical assumptions at the IP-policy level have their limitations. They may overlook the real impact and influence of the suggested mechanisms on the economic behavior of the relevant market players. With this in mind, the envisaged instruments and their legal design (e.g. term, subject and form of exclusivity extension, transferability, etc.) have to be analyzed in view of their expected market impact in order to verify whether the desired incentives will actually be effective. Economic research is therefore an important part of the interdisciplinary research agenda in this field and deserves special consideration in this section.

Dating back at least to the theoretical contributions of William Nordhaus in $1969,{ }^{209}$ economic research aims at understanding the relationship between IPbased incentives and $\mathrm{R} \& \mathrm{D}$ investments. IP rights are intended to alleviate the problem of private under-investment in research by granting innovators periods of market exclusivity for their invention. By granting temporary monopoly protection to an invention, IP rights incentivize firms to invest in R\&D that would not have been conducted otherwise. However, temporary monopoly protection simultaneously causes static inefficiencies by allowing for higher consumer prices than those

\footnotetext{
207 See Sect. 2.1 above.

208 See Sects. 4.1 and 4.2 above.

209 Nordhaus (1969).
} 
in more competitive environments. ${ }^{210}$ Furthermore, IP rights might avoid agency problems resulting from public-sector control over research by having a marketbased innovation reward scheme. ${ }^{211}$ It is therefore of core economic interest to understand the optimal IP policy concerning the legal design of such a system. ${ }^{212}$ Besides IP incentives there are also other instruments, like innovation prizes, that are intended to foster innovation. ${ }^{213}$

The IP system has attracted special attention with respect to the development of new drugs, given that industry experts consider patents to be a particularly important tool for protecting and incentivizing pharmaceutical innovation. ${ }^{214}$ This is primarily due to the lengthy, risky and costly drug development process $^{215}$ as a result of strict regulatory requirements for marketing authorization (e.g. the Declaration of Helsinki). This process creates long commercialization lags and, thus, short effective market exclusivity periods to recoup R\&D costs. ${ }^{216}$ Researchers have investigated the relationship between market size, ${ }^{217}$ price regulation, ${ }^{218}$ market exclusivity, ${ }^{219}$ and pharmaceutical innovations. Nevertheless, empirical evidence on the optimal parameters of IP systems is scarce since it involves various empirical challenges. ${ }^{220}$

\subsubsection{Empirical Challenges}

Conceptually, an analysis of the effectiveness and efficiency of IP systems requires the quantification of additional $R \& D$ investments in the sense that scientifically feasible $R \& D$ investments are only undertaken due to the incentives generated by a specific IP scheme. ${ }^{221}$ However, this involves challenges concerning the causal inference of additional pharmaceutical R\&D efforts and its measurement.

Empirical research on innovation incentives in pharmaceutical markets requires finding informative data and developing measures for research efforts. Many studies rely on patent measures ${ }^{222}$ or launched/registered drugs $^{223}$ that are both easily

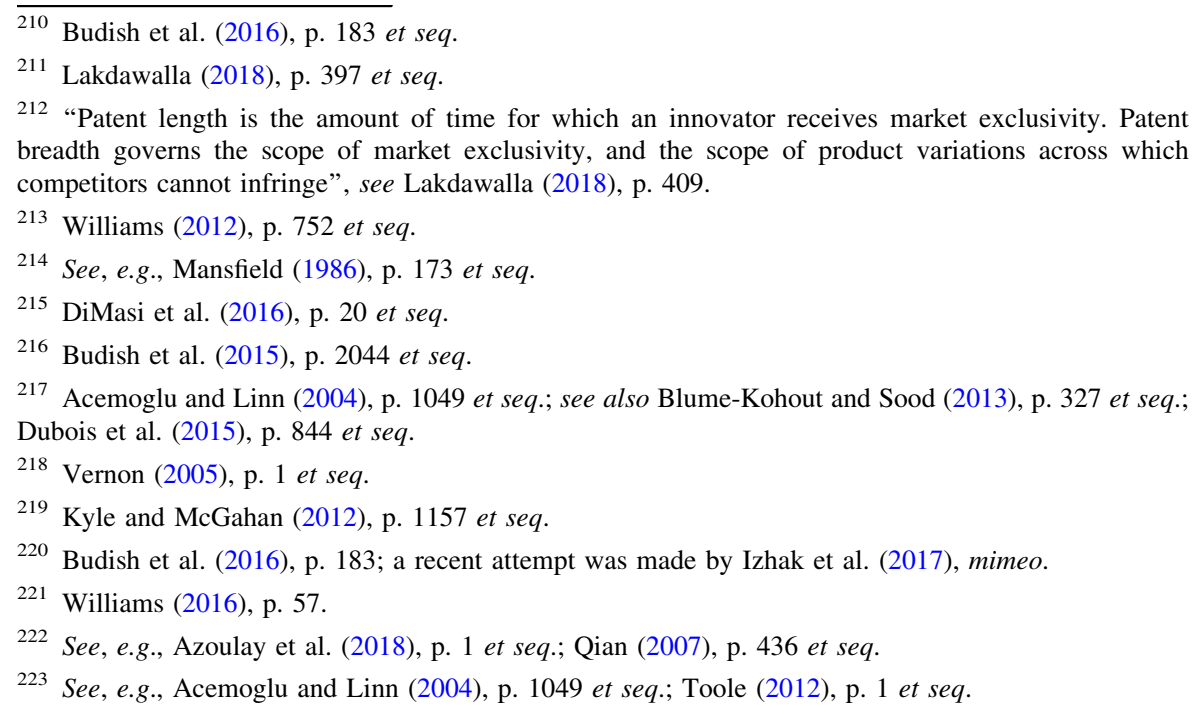


observable from public registries. Unfortunately, new chemical entities or patent measures only capture early stage efforts, and registered drugs take no account of promising drug compounds (as well as the financial efforts undertaken) that were abandoned. More recently, researchers have acquired access to proprietary databases that comprise data on clinical trials which allow investigating the relationship of the research pipeline of pharmaceutical firms and IP policy. ${ }^{224}$ However, this data is incomplete for time periods before $1999 .{ }^{225}$ Since a large share of IP policy variation occurred in the 1980s and 1990s, precise economic research relies on pharmaceutical companies opening up their internal records on research and development efforts for these years. The same applies to firms' expectations of market demand, scientific opportunities, or the expected time spent until the product launch at the narrow disease level. ${ }^{226}$

Economic research aims at understanding which private $R \& D$ investments are "effectively" added due to a specific public innovation incentive. Therefore, causal inference relies on estimating the quantity and type of such effective additional R\&D investment and to compare it with carefully identified counterfactual scenarios. This requires the identification of variation in IP systems across otherwise similar potential inventions in order to disentangle the effects resulting from the IP system and alternative explanations. ${ }^{227}$ The main challenge is to find appropriate variation within a - to a large extent - uniform IP system. In previous research this was often crosscountry variation, e.g. the introduction of new IP systems in some countries, ${ }^{228}$ or variation between different sub-groups, like different disease and treatment types, with regard to the effective market exclusivity term. ${ }^{229}$

\subsubsection{Potential Economic Research Contributions}

Designing an EU policy to foster the development of new antimicrobial drugs requires a thorough empirical analysis that captures the various parameters of the intended instrument. As described in previous sections, the EU could grant additional patent or SPC protection terms and, hence, additional market exclusivity to a new chemical entity in the field of antimicrobials. Moreover, the regulators could allow for the possibility of this extension to be assigned to another drug contained in the active patent portfolio of the sponsoring company (so-called wildcard extensions) or to be transferable to third parties. Whether economic research

\footnotetext{
$\overline{224}$ See, e.g., Kyle and McGahan (2012), p. 1157 et seq.; Blume-Kohout and Sood (2013), p. 327 et seq.; Krieger et al. (2018), mimeo.

225 "The Food and Drug Administration Modernization Act, passed in late 1997 and enacted in 1999, required the reporting of clinical trials to a centralized government registry. Even though [the authors] observe some drug candidates pre-1999, [they] believe that [the] data provides fuller coverage post1999”, from Krieger et al. (2018), mimeo, p. 8.

226 See, e.g., Williams (2016), p. 57, who points in a similar direction.

227 Williams (2016), p. 53 et seq.

228 See, e.g., Qian (2007), p. 436 et seq. However, these empirical studies often find no effects of IP system changes due to the insufficient market size of single countries, as argued by Williams (2016), p. 61 .

229 Budish et al. (2015), p. 2044 et seq.; Gaessler and Wagner (2018), mimeo.
} 
can support the design of such an innovation incentive depends on the possibility of finding answers to the measurement and inference challenges.

Economic research should not only focus on the potential effectiveness of these policies but also on their (social) costs. It has been shown that longer market exclusivity periods lead to substantial increases in public healthcare expenditures, ${ }^{230}$ which can also induce substantial welfare losses. ${ }^{231}$ Therefore, economic research should also consider a detailed analysis of the costs, particularly in an EU setting, associated with any new innovation incentive scheme for antimicrobials, especially if it involves uncertainty with regard to market outcomes like transferable IP extensions.

Historical changes in IP incentives, changes in the law for instance, and historical data can serve as a source of variation to conduct a counterfactual analysis of the questions above. While the literature has - if at all - focused on the introduction of national patent policies, ${ }^{232}$ increasing the strength of patents, ${ }^{233}$ extending the patent length, e.g. by TRIPS, ${ }^{234}$ and other alternative measures to protect pharmaceutical innovation, such as data exclusivity, ${ }^{235}$ there are IP and innovation incentives that have not yet captured major academic interest. These policies are aimed at solving innovation incentive problems concerning specific under-invested disease or treatment types, which could be comparable to antimicrobials. These are, inter alia, priority review vouchers for neglected diseases, pediatric (SPC) extensions, and the orphan drugs designation in the US or EU. Furthermore, there are various innovation prizes in pharmaceutical markets. These are comparable to transferable wild-card SPC extensions, since the expected revenue from transferring a wild-card SPC to a third party and the expected cash-flow coming from innovation prizes are similar incentive mechanisms.

\subsubsection{Analysis Based on Historical Events and Data}

Priority review vouchers for neglected tropical diseases (NTD) were proposed by academics in $2006^{236}$ and introduced in the US in 2007. They provide financial incentives to develop tropical disease products. Sponsors receive a "priority review voucher" if a new drug that targets one of at least 16 listed tropical diseases obtains approval. The priority review voucher can be used for sponsors' own subsequent drugs or be sold to third parties. ${ }^{237}$ In comparison to a transferable wild-card SPC, the priority review voucher allows drugs to enter the market earlier. Early studies find that some vouchers have already been awarded, with selling prices reaching as

\footnotetext{
230 See, e.g., Kesselheim et al. (2006), pp. 1637-1647.

231 Yin (2017), mimeo.

232 See, e.g., Qian (2007), p. 436 et seq.

233 Sakakibara and Branstetter (2001), p. 77 et seq.

234 Kyle and McGahan (2012), p. 1157 et seq.

235 Gaessler and Wagner (2018), mimeo.

236 Ridley et al. (2006), p. 313 et seq.

237 Berman and Radhakrishna (2017), p. 11 et seq.
} 
high as $\$ 350$ million. ${ }^{238}$ However, the studies conducted so far lack a counterfactual analysis. They do not discuss whether or not these NTD drugs would have been developed in the absence of the program. ${ }^{239}$ A potential approach would be to compare the research efforts on diseases at the threshold of becoming eligible for the program. In this sense, we can learn from the NTD priority voucher policy to the extent that we can analyze whether transferable market exclusivity yields additional targeted treatments.

Pediatric extensions grant additional market exclusivity periods to new drugs if clinical trials were also conducted with children. However, the six-month extension of the patent term (US) ${ }^{240}$ or the SPC term (EU) does not only apply to the pediatric usage of the drug but also to the new compound as such. This policy is comparable to wild-card SPC extension in the sense that the IP term of a distinct product, here drugs for adult patients, is extended in order to incentivize clinical research on children. Early research shows that pediatric studies were primarily conducted for drugs with larger sales in adult markets than for drugs that are medically important to children. ${ }^{241}$ Unfortunately, empirical research on pediatric extensions in a European setting, as well as on the SPC system, is scarce. To the best of our knowledge no causal analysis exists on the effectiveness of the EU SPC system with regard to the direction of $\mathrm{R} \& \mathrm{D}$ efforts, especially due to the absence of data on disease-specific R\&D investments prior to the SPC/pediatric introduction, as well as estimates on the firms' expected commercialization lags for new compounds, which is an important determinant of the expected SPC term.

The US Orphan Drug Act (ODA), implemented in 1983, grants an innovator the right to market an eligible orphan drug exclusively for a specific indication for seven years after its approval for marketing. ${ }^{242}$ Although it grants the exclusivity extension specifically to the new compound, it aims at solving issues of underinvestment concerning a specific disease type. Research finds that the ODA led to a significant increase in new clinical trials among more prevalent rare diseases, but not for less prevalent rare diseases. However, the effect is driven by the tax credits associated with the Orphan Drug Act. ${ }^{243}$ These results are also in line with other findings on the ODA, reporting the increase in new drug introductions for rare diseases compared to non-rare diseases. ${ }^{244}$ Changes in the market for rare disease treatments have albeit recently called into question the success of the ODA. ${ }^{245}$ Orphan drug designations were also introduced in the European system in 2000 but

\footnotetext{
238 Ibid., p. 12.

239 Kerr et al. (2018); Stefanakis et al. (2012); Berman and Radhakrishna (2017) point out concerns that some "vouchers have been awarded for products that are not novel because they were already sold worldwide", see Berman and Radhakrishna (2017), p. 13.

240 Lakdawalla (2018), p. 409.

241 Olson and Yin (2017), p. 1 et seq.

242 Lakdawalla (2018), p. 408.

243 Yin (2008), p. 1060 et seq.

244 Lichtenberg and Waldfogel (2009), p. 335 et seq.

245 Bagley et al. (2019), p. 97 et seq.
} 
have not yet been analyzed. Following recent approaches, ${ }^{246}$ the success of the European ODA could be evaluated by comparing investments in affected subfields with non-affected subfields before and after the 2000 introduction in order to understand the investment elasticity with regard to extension periods.

When focusing on the prize character of potential transferable exclusivity or wild-card extensions, one could also attempt to analyze the effectiveness and costs of existing Medical Innovation Prize Funds ${ }^{247}$ and Advance Market Commitments. $^{248,249}$ While the theoretical literature on innovation prizes is well developed, ${ }^{250}$ few economic studies exist that have conducted a counterfactual analysis. $^{251}$ Most studies have analyzed historical prizes from the 19th or 20th century. These studies find general positive effects on inventive activities ${ }^{252}$ and of small-scale innovation prizes ${ }^{253}$ in various non-health industries. They provide, for instance, evidence on complementarities between prizes and patents. ${ }^{254}$ Similar to any IP incentive, policymakers need ways to estimate what prize size would be appropriate. However, there is considerable debate on whether innovation prize systems are more efficient than market prizes or vice versa. ${ }^{255}$

\subsubsection{Alternative Methods}

Field experiments are another attempt to answer questions about the optimal policy parameters. These have already been proposed by researchers to investigate the effectiveness of innovation policy, and are considered to be a promising area for future research. ${ }^{256}$ Besides conducting explicit randomized control trials, some researchers argue that partial randomization should be built into the grant process of existing research and innovation grant programs. ${ }^{257}$ Field experiments allow, by construction, for a counterfactual analysis, conditional on a random allocation of the treatment. Randomization ensures that treatment and control groups are similar in the absence of the new innovation incentive system so that different outcomes in terms of R\&D investments can be causally interpreted. Economic literature about field experiments on innovation prizes or intellectual property rights is scarce. The few research contributions involve small-scale experiments on the problem-solving

\footnotetext{
246 Kim et al. (2018).

247 Williams (2012), p. 768 et seq., describes for instance the Archon X Prize that awards \$10 million to the first team sequencing 100 whole human genomes.

248 Kremer and Williams (2010), p. 1 et seq.

249 Advance purchase commitments relate to the findings of Acemoglu and Linn (2004), who show that the entry of new drugs relates positively to the expected market size (linked to demographic changes).

250 See, e.g., Wright (1983), p. 343 et seq; Galasso et al. (2018), p. 343 et seq.

251 Williams (2012), p. 770.

252 See, e.g., Brunt et al. (2012), p. 657 et seq.

253 See, for an exemplary overview, Williams (2012), p. 752.

254 Burton and Nicholas (2017), p. 21 et seq.; Moser and Nicholas (2013), p. 763 et seq.

255 Spulber (2015), p. 690 et seq.; Roin (2014), p. 999 et seq.

256 Williams (2012), p. 771; Bakhshi et al. (2015), p. 1462 et seq.

257 Jaffe (2002), p. 22 et seq.
} 
performance of knowledge workers ${ }^{258}$ or on innovation vouchers that grant financial support ex ante and not ex post. ${ }^{259}$

In the specific case of transferable or wild-card exclusivity extensions for new antimicrobial drugs, a field experiment could, for instance, comprise an initial application phase in which it is decided whether firms can participate in a contest for an innovation prize/IP term extension or not. Applicants are randomly allocated to various subgroups, e.g. transferable wild-card extension/innovation prizes with different parameters, like extending period/size, and no participation in the contest. Researchers can then compare the outcomes of the subgroups, which differ only with regard to the treatment, and infer how pharmaceutical firms react to different incentive schemes. However, these experiments might raise ethical concerns, which are not discussed here, and take considerable time to yield results.

\subsubsection{Summary}

The preceding section has elaborated on the necessity for a thorough empirical analysis of any innovation and IP incentive scheme being proposed by the regulators to foster the development of new antimicrobial drugs. This applies especially to the determination of the specific policy parameters in order to create an effective and cost-efficient system. We have summarized recent evidence on the relationship between pharmaceutical patents and innovation and have highlighted the empirical challenges of analyzing any innovation policy. Investigating prior variation in innovation/IP policy will rely on having access to data on pharmaceutical companies' research pipelines in order to assess how the introduction of these policies has effectively altered firms' $R \& D$ investment behavior. This requires the careful construction of a clear counterfactual study that allows a comparison as to what would have happened in the absence of the policy. Furthermore, we describe alternative methods, namely the implementation of field experiments, to analyze innovation policies that encourage antimicrobial treatment development.

\section{Conclusions}

Studies in the fields of biology and pharmacology should clarify the dimensions of the antimicrobial crisis, and help to determine which kind of innovation is needed. Legal analysis can identify the options available for adapting existing IP incentives to specific features of the antimicrobial market. Economic studies in turn can evaluate hypotheses on the effects of each model on R\&D investments as well as innovations and their possible costs also for society. However, economic assessments rely on ex post analyses of historical events or field experiments to draw causal conclusions as to the effects of IP parameters. This research comes with significant limitations in the context of IP in pharmaceutical markets due to the restricted access to proprietary data, e.g. the selection criteria on pharmaceutical

\footnotetext{
258 See, e.g., Boudreau and Lakhani (2015), p. 4 et seq.

259 See, e.g., Heite et al. (2018), mimeo; Bakhshi et al. (2015), p. 1462 et seq.
} 
R\&D. In order to provide answers concerning the effective ability of incentive schemes in generating innovation that would otherwise not take place, economic research has to find comparable events to infer the causal impact of IP parameters on surplus R\&D. The same applies for any assessment of the costs incurred by the additional incentive. ${ }^{260}$

With this in mind, one possible approach could be to introduce some of the options considered in this paper in an experimental setting, such as longer exclusivities or transferable vouchers, and collect new data on their impact on the investment decisions of innovators ${ }^{261}$ and the costs of the measure for society. ${ }^{262}$ Such data could then inform the determination of whether or not such instruments ought to become a stable feature of the EU IP legal landscape. This approach relates to the aforementioned U.S. Bill H.R. 6294, under which no more than ten extensions are to be possible. Such an experimental approach is meaningful when there is a consensus established that an antimicrobial crisis exists and requires action for fostering research in new active ingredients.

When assessing the options, the international perspective should not be neglected. The effectiveness of an incentive depends on the size of the market to which it applies. Joint initiatives involving other important pharmaceutical markets - such as Japan and the US - may reduce the burden for EU taxpayers and the term of extensions that ad hoc legislation may introduce. Preferences for one of the options considered should therefore take into account its ability to attract consensus among WTO members. Any initiative that is targeted towards the EU market should be supplemented by symmetrical efforts to include the instruments concerned within the framework of binding FTA agreements or consensual joint initiatives.

Acknowledgements Open access funding provided by the Max Planck Society.

Open Access This article is distributed under the terms of the Creative Commons Attribution 4.0 International License (http://creativecommons.org/licenses/by/4.0/), which permits unrestricted use, distribution, and reproduction in any medium, provided you give appropriate credit to the original author(s) and the source, provide a link to the Creative Commons license, and indicate if changes were made.

\footnotetext{
260 The economic implications of the antimicrobial crisis itself - for instance, the costs of inaction - are based on assumptions and predictions.

261 For instance, the number of clinical trials or the number of marketing authorizations granted for an antimicrobial indication. Data restrictions could be attenuated, for example, by providing legal information obligations.

262 Some data will be available, other data are confidential. The costs of longer exclusivities can be approximated by simple back-of-the-envelope calculations. For instance, researchers can calculate the revenues generated by a drug during the period of exclusivity extension and compare it with the revenues generated after the expiration of the exclusion right for a period of equal length. The revenue after expiration is composed of entities sold by the originator - at potentially lower prices due to competition and by the competitors. However, reactions to demand should be taken into account.
} 


\section{References}

Acemoglu D, Linn J (2004) Market size in innovation: theory and evidence from the pharmaceutical industry. Q J Econ 119(3):1049-1090

Aldous G, Falconer D, Aldous W (1965) Terrel on the law of patents, 11th edn. Sweet \& Maxwell, London

Angulo FJ, Collignon P, Powers JH, Chiller TM, Aidara-Kane A, Aarestrup FM (2009) World Health Organization ranking of antimicrobials according to their importance in human medicine: a critical step for developing risk management strategies for the use of antimicrobials in food production animals. Clin Infect Dis 49(1):132-141

Årdal C, Findlay D, Savic M, Carmeli Y, Gyssens I, Laxminarayan R, Outterson K, Rex JH (2018) DRIVE-AB report-revitalizing the antibiotic pipeline: stimulating innovation while driving sustainable use and global access. https://carb-X.org/wp-content/uploads/2018/01/DRIVE-AB_ Final_Report-Jan2018.pdf. Accessed 25 Nov 2018

Azoulay P, Graff Zivin JS, Li D, Sampat BN (2018) Public R\&D investments and private-sector patenting evidence from NIH funding rules. Rev Econ Stud 0:1-36

Bagley N, Berger B, Chandra A, Garthwaite C, Stern AD (2019) The Orphan Drug Act at 35: observations and an outlook for the twenty-first century. Innov Policy Econ 19(1):97-137

Bakhshi H, Edwards JS, Roper S, Scully J, Shaw D, Morley L, Rathbone N (2015) Assessing an experimental approach to industrial policy evaluation: applying RCT + to the case of creative credits. Res Policy 44(8):1462-1472

Barder O, Kremer M, Williams H (2006) Advance market commitments, The Economists' Voice Feb 2006:1-6. https://economics.mit.edu/files/6809. Accessed 25 Nov 2018

Batista PHD, Romandini R (2018) Antibiotics. In: Romandini R, Hilty RM, Kur A (eds) Study on the legal aspects of supplementary protection certificates in the EU, pp 435-447. https://ec.europa.eu/ supplementaryprotectioncertificatesdocsroom/documents/29524. Accessed 25 Nov 2018

Becker D, Selbach M, Rollenhagen C, Ballmaier M, Meyer TF, Mann M, Bumann D (2006) Robust salmonella metabolism limits possibilities for new antimicrobials. Nature 440(7082):303-307

Berman J, Radhakrishna T (2017) The tropical disease priority review voucher: a game-changer for tropical disease products. Am J Trop Med Hyg 96(1):11-13

Blume-Kohout ME, Sood N (2013) Market size and innovation: effects of medicare part D on pharmaceutical research and development. J Public Econ 97:327-336

Boucher HW, Talbot GH, Bradley JS, Edwards JE, Gilbert D, Rice LB, Scheld M, Spellberg B, Bartlett J (2009) Bad bugs, no drugs: No ESKAPE! An update from the Infectious Diseases Society of America. Clin Infect Dis 48(1):1-12. https://doi.org/10.1086/595011. https://academic.oup.com/cid/ article/48/1/1/288096. Accessed 25 Nov 2018

Boudreau KJ, Lakhani KR (2015) "Open" disclosure of innovations, incentives and follow-on reuse: theory on processes of cumulative innovation and a field experiment in computational biology. Res Policy 44(1):4-19

Broes S, Schumacher S, Preuveneers G, Huys I (2016) Intellectual property rights and regulatory exclusivities in the pharmaceutical sector: challenges and future improvements. In: IPQ 2016, pp 19-43

Brogan DM, Mossialos E (2006) Applying the concepts of financial options to stimulate vaccine development. Nat Rev Drug Discov 5(8):641-647

Brogan DM, Mossialos E (2013) Incentives for new antibiotics: the options market for antibiotics (OMA) model. Global Health 9(1):58

Brogan DM, Mossialos E (2016) Systems, not pills. Soc Sci Med 151:167-172

Brunt L, Lerner J, Nicholas T (2012) Inducement prizes and innovation. J Ind Econ 60(4):657-696

Budish E, Roin BN, Williams H (2015) Do firms underinvest in long-term research? Evidence from cancer clinical trials. Am Econ Rev 105(7):2044-2085

Budish E, Roin BN, Williams H (2016) Patents and research investments: assessing the empirical evidence. Am Econ Rev 106(5):183-187

Burton MD, Nicholas T (2017) Prizes, patents and the search for longitude. Explor Econ Hist 64:21-36

Butler MS, Blaskovich MAT, Cooper MA (2017) Antibiotics in the clinical pipeline at the end of 2015. J Antibiot 70:3-24. https://www.nature.com/articles/ja201672. Accessed 25 Nov 2018 
Calfee DP (2017) Recent advances in the understanding and management of klebsiella pneumoniae. F1000Res 6(1760). https://www.ncbi.nlm.nih.gov/pmc/articles/PMC5621103/\#. Accessed 25 Nov 2018

Cars O, So A, Högberg L, Manz C (2008) Innovating for antibacterial resistance. ESCMID News 2(23):22-24

Cassini A, Högberg LD, Plachouras D, Quattrocchi Hoxha A, Simonsen GS, Colomb-Cotinat M, Kretzschmar ME, Devleesschauwer B, Cecchini M, Ouakrim DA, Oliveira TC, Struelens MJ, Suetens C, Monnet DL (2018) Attributable deaths and disability-adjusted life-years caused by infections with antibiotic-resistant bacteria in the EU and the European Economic Area in 2015: a population-level modelling analysis. Lancet Infect Dis. https://doi.org/10.1016/S14733099(18)30605-4. https://www.thelancet.com/journals/laninf/article/PIIS1473-3099(18)30605-4/ fulltext. Accessed 25 Nov 2018

Center for Infectious Disease Research and Policy (2018) Novartis drops antibiotic development program, CIDRAP. http://www.cidrap.umn.edu/news-perspective/2018/07/novartis-drops-antibiotic-develop ment-program. Accessed 25 Nov 2018

Centers for Disease Control and Prevention (2013) Antibiotic resistance threats in the United States. https://www.cdc.gov/drugresistance/pdf/ar-threats-2013-508.pdf. Accessed 25 Nov 2018

Chorzelski S, Grosch B, Rentmeister H, Völler S, Landré B, Pfitzner J, Wechselmann C, Busse R, Edwards S, Henschke C (2015) Boston Consulting Group-breaking through the wall—enhancing research and development of antibiotics in science and industry. https://docplayer.net/8855152Breaking-through-the-wall.html. Accessed 25 Nov 2018

Clift C, Gopinathan U, Morel C, Outterson K, Røttingen JA, So A (2015) Towards a new global business model for antibiotics-delinking revenues from sales. Chatham House Report, London. https:// www.chathamhouse.org/sites/default/files/field/field_document/

20151009NewBusinessModelAntibioticsCliftGopinathanMorelOuttersonRottingenSo.pdf. Accessed 25 Nov 2018

Coates ARM, Halls G, Hu Y (2011) Novel classes of antibiotics or more of the same? Br J Pharmacol 163(1):184-194. https://www.ncbi.nlm.nih.gov/pmc/articles/PMC3085877/. Accessed 25 Nov 2018

Cook T (2016) Pharmaceuticals biotechnology and the law, 3rd edn. Springer, London

De Carvalho NP (2010) The TRIPS regime of patent rights, 3rd edn. Kluwer Law International, Alphen aan den Rijn

DiMasi JA, Grabowski HG, Hansen RW (2016) Innovation in the pharmaceutical industry: new estimates of R\&D costs. J Health Econ 47:20-33

Dubois P, De Mouzon O, Scott-Morton F, Seabright P (2015) Market size and pharmaceutical innovation. RAND J Econ 46(4):844-871

Duffy JF (2004) Rethinking the prospect theory of patents. Univ Chic Law Rev 71(2):439-510

European Commission (2017) A European one health action plan against antimicrobial resistance (AMR). https://ec.europa.eu/health/amr/sites/amr/files/amr_action_plan_2017_en.pdf. Accessed 25 Nov 2018

European Parliament, European Parliament resolution of 13 September 2018 on a European One Health Action Plan against Antimicrobial Resistance (AMR) (2017/2254(INI)), P8_TA-PROV(2018)0354. http://www.europarl.europa.eu/sides/getDoc.do?pubRef=-//EP//TEXT+TA+P8-TA-2018$0354+0+\mathrm{DOC}+\mathrm{XML}+\mathrm{V} 0 / / \mathrm{EN} \&$ language $=\mathrm{EN}$. Accessed 25 Nov 2018

Forsyth C (2013) Repairing the antibiotic pipeline: Can the Gain Act do it? Wash J Law 9(1):1-18

French Agency for Food, Environmental and Occupation Health \& Safety (2014) Assessment of the risks of emergence of antimicrobial resistance associated with modes of antibiotic use in the field of animal health. https:/www.anses.fr/fr/system/files/SANT2011sa0071RaEN.pdf. Accessed 25 Nov 2018

Gaessler F, Wagner S (2018) Patents, data exclusivity, and the development of new drugs. Mimeo

Galasso A, Mitchell M, Virag G (2018) A theory of grand innovation prizes. Res Policy 47(2):343-362

Glennerster R, Kremer M (2000) A better way to spur medical research and development. Regulation 23(2):34-39

Gollaher DL, Milner PG (2012) Promoting antibiotic discovery and development—a California Healthcare Institute initiative. www.chi.org/uploadedFiles/Industry_at_a_glance/CHI\% 20Antibiotic\%20White\%20Paper_FINAL.pdf. Accessed 25 Nov 2018

González-Bello C (2017) Antibiotic adjuvants-a strategy to unlock bacterial resistance to antibiotics. Bioorg Med Chem Lett 27:4221-4228 
Grosse Ruse-Khan H, Romandini R (2017) Patentability of pharmaceutical inventions under TRIPS: domestic court practice as a test for international policy space. In: Mercurio B, Kim D (eds) Contemporary issues in pharmaceutical patent law. London, pp 9-46. Max Planck Institute for Innovation \& Competition Research Paper No. 16-02. https://ssrn.com/abstract=2736224. Accessed 25 Nov 2018

Harris T, Nicol D, Gruen N (2013) Pharmaceutical patents review report. Canberra

Heite J, Huber LR, Kleine M (2018) The effect of innovation vouchers on innovation activity and performance of SMEs in the UK-a randomized controlled trial. Mimeo

Kim Y, Chatterjee C, Higgins, MJ (2018) Moving beyond the valley of death: regulation and venture capital investments in early-stage biopharmaceutical firms. National Bureau of Economic Research No. w25202

Hoffman SJ, Caleo GM, Daulaire N, Elbe S, Matsoso P, Mossialos E, Rizvi Z, Røttingen JA (2015) Strategies for achieving global collective action on antimicrobial resistance. Bull World Health Organ 93(12):867-876

Höjgård S (2012) Antibiotic resistance-Why is the problem so difficult to solve? Infect Ecol Epidemiol 2(1):18165. https://www.ncbi.nlm.nih.gov/pmc/articles/PMC3426322/. Accessed 25 Nov 2018

Horowitz JB, Moehring HB (2004) How property rights and patents affect antibiotic resistance. Health Econ 13(6):575-583

Hwang TJ, Carpenter D, Kesselheim AS (2014) Target small firms for antibiotic innovation. Science 344(6187):967-969

IFPMA-International Federation of Pharmaceutical Manufacturers \& Associations (2018) Policy position: the need for AMR R\&D pull incentives. https://www.ifpma.org/wp-content/uploads/2018/ 09/IFPMA_AMR_Position_Incentives_Pull_2018.pdf. Accessed 25 Nov 2018

Izhak O, Saxell T, Takalo T (2017) Patent duration, breadth and costly imitation: evidence from the US pharmaceutical market. Mimeo

Jacznska E, Outterson K, Mestre-Ferrandiz J (2015) Business model options for antibiotics-learning from other industries. Chatham House, London. https://papers.ssrn.com/sol3/papers.cfm?abstract_ id=2569183. Accessed 25 Nov 2018

Jaffe AB (2002) Building programme evaluation into the design of public research support programmes. Oxf Rev Econ Policy 18(1):22-34

Kades E (2005) Preserving a precious resource: rationalizing the use of antibiotics. Nw UL Rev 99:611-675

Kapczynski A (2009) Commentary: innovation policy for a new era. J Law Med Ethics 37(2):264-268

Karst K (2018) PCAST Recommendation in action: "wildcard exclusivity" proposed for "priority antimicrobial products". http://www.fdalawblog.net/2018/07/pcast-recommendation-in-actionwildcard-exclusivity-proposed-for-priority-antimicrobial-products/. Accessed 25 Nov 2018

Kerr KW, Henry TC, Miller KL (2018) Is the priority review voucher program stimulating new drug development for tropical diseases? PLoS Negl Trop Dis 12(8):e0006695

Kesselheim AS, Outterson K (2010) Fighting antibiotic resistance: marrying new financial incentives to meeting public health goals. Health Aff 29(9):1689-1696

Kesselheim AS, Outterson K (2011) Improving antibiotic markets for long term sustainability. Yale J Health Pol Law Ethics 11(1):101-168

Kesselheim AS, Fischer MA, Avorn J (2006) Extensions of intellectual property rights and delayed adoption of generic drugs: effects on Medicaid spending. Health Aff 25(6):1637-1647

Kraßer R, Ann C (2016) Patentrecht, 7th edn. C.H. Beck, Munich

Kremer M, Williams H (2010) Incentivizing innovation: adding to the tool kit. Innov Policy Econ 10(1):1-17

Krieger JL, Li D, Papanikolaou D (2018) Developing novel drugs. National Bureau of Economic Research No. w24595

Kumar M, Curtis A, Hoskins C (2018) Application of nanoparticle technologies in the combat against anti-microbial resistance. Pharmaceutics 14(10). https://doi.org/10.3390/pharmaceutics10010011. https://www.mdpi.com/1999-4923/10/1/11/pdf. Accessed 25 Nov 2018

Kyle M (2017) Economic analysis of supplementary protection certificates in Europe. European Commission/MINES ParisTech (CERNA) working paper. https://ec.europa.eu/docsroom/ documents/25621/attachments/1/translations/en/renditions/pdf. Accessed 25 Nov 2018

Kyle MK, McGahan AM (2012) Investments in pharmaceuticals before and after TRIPS. Rev Econ Stat 94(4):1157-1172

Lakdawalla DN (2018) Economics of the pharmaceutical industry. J Econ Lit 56(2):397-449 
Lee Ventola C (2015) The antibiotic resistance crisis-part 1: causes and threats. Pharm Ther 40(4):277-283

Leekha S, Terrell CL, Edson RS (2011) General principles of antimicrobial therapy. Mayo Clin Proc 86(2):156-167

LeMieux J (2018) As Novartis exits, who will make new antibiotics? Genetic Engineering and Biotechnology News. https:/www.genengnews.com/insights/as-novartis-exits-who-will-make-newantibiotics/. Accessed 25 Nov 2018

Levine R, Kremer M, Albright A (2005) Making markets for vaccines. https://www.cgdev.org/sites/ default/files/archive/doc/books/vaccine/MakingMarkets-complete.pdf. Accessed 25 Nov 2018

Lichtenberg FR, Waldfogel J (2009) Does misery love company-evidence from pharmaceutical markets before and after the Orphan Drug Act. Michigan Telecommun Technol Law Rev 15(2):335-357

Love J (2014) Alternatives to the patent system that are used to support R\&D efforts, including both push and pull mechanisms, with a special focus on innovation-inducement prizes and open source development models. WIPO doc. CDIP/14/INF/12. https://www.wipo.int/meetings/en/doc_details. jsp?doc_id=287218. Accessed 25 Nov 2018

Love J, Hubbard T (2007) The big idea: prizes to stimulate R\&D for new medicines. Chic Kent Law Rev $82: 1519-1554$

Love J, Hubbard T (2009) Prizes for innovation of new medicines and vaccines. Ann Health Law 18(2):155-186

Mansfield E (1986) Patents and innovation: an empirical study. Manag Sci 32(2):173-181

Mölstad S, Cars O (2009) Major change in the use of antibiotics following a national programme: Swedish strategic programme for the rational use of antimicrobial agents and surveillance of resistance (STRAMA). Scand J Infect Dis 31(2):191-195

Monteagudo-Chu MO, Shaeishaa N (2017) Duration of antibiotic therapy: general principles. PharmacyTimes. https://www.pharmacytimes.com/publications/health-system-edition/2017/ july2017/duration-of-antibiotic-therapy-general-principles. Accessed 25 Nov 2018

Morel CM (2011) Exploring responses to the need for new antibiotics. Brussels. https://www.reactgroup. org/uploads/publications/react-publications/Exploring-Responses-to-the-need-for-new-antibiotics. pdf. Accessed 25 Nov 2018

Morel CM, Mossialos E (2010) Stoking the antibiotic pipeline. BMJ 340:1115-1118

Moser P, Nicholas T (2013) Prizes, publicity and patents: non-monetary awards as a mechanism to encourage innovation. J Ind Econ 61(3):763-788

Mossialos E, Morel CM, Edwards S, Berenson J, Gemmill-Toyama M, Brogan D (2010) Policies and incentives for promoting innovation in antibiotic research. http://www.euro.who.int/_data/assets/ pdf_file/0011/120143/E94241.pdf. Accessed 25 Nov 2018

Mueller-Langer F (2013) Neglected infectious diseases: are push and pull incentive mechanisms suitable for promoting drug development research? Health Econ Policy Law 8:185-208

National Collaborating Centre for Women's and Children's Health (UK) (2012) Antibiotics for earlyonset neonatal infection: antibiotics for the prevention and treatment of early-onset neonatal infection. NICE Clinical Guidelines (149). https://www.ncbi.nlm.nih.gov/books/NBK116613/. Accessed 25 Nov 2018

Nickas M (2012) A patent prize system to promote development of new antibiotics and conservation of existing ones. Pitt J Tech L Pol'y 12(5). https://tlp.law.pitt.edu/ojs/index.php/tlp/article/view/98/ 105. Accessed 25 Nov 2018

Nordhaus W (1969) Invention, growth, and welfare: a theoretical treatment of technological change. MIT Press, Cambridge

O'Neill J (2015) Securing new drugs for future generations: the pipeline of antibiotics - the review on antimicrobial resistance. https://amr-review.org/sites/default/files/SECURING\%20NEW\% 20DRUGS\%20FOR\%20FUTURE\%20GENERATIONS\%20FINAL\%20WEB_0.pdf. Accessed 25 Nov 2018

O’Neill J (2016) Tackling drug-resistant infections globally: final report and recommendations-the review on antimicrobial resistance. https://amr-review.org/sites/default/files/160518_Final\% 20paper_with\%20cover.pdf. Accessed 25 Nov 2018

Olson MK, Yin N (2017) Examining firm responses to R\&D policy: an analysis of pediatric exclusivity. Am J Health Econ 4(3):1-64

Outterson K (2005) The vanishing public domain. Univ Pittsbg Law Rev 2005(67):67-123

Outterson K (2010) Legal ecology of resistance, Cardozo L Rev forthcoming:613-678. https://papers. ssrn.com/sol3/papers.cfm?abstract_id=1492150. Accessed 25 Nov 2018 
Outterson K (2014) New business models for sustainable antibiotics. Boston Univ. School of Law Research Paper No. 14-10. https://papers.ssrn.com/sol3/papers.cfm?abstract_id=2397957\#. Accessed 25 Nov 2018

Outterson K (2018) Innovative ways to pay for new antibiotics will help fight superbugs. https://www. statnews.com/2018/04/11/innovation-new-antibiotics-fight-superbugs/. Accessed 4 Jan 2019

Outterson K, McDonnell A (2016) Funding antibiotic innovation with vouchers: recommendations on how to strengthen a flawed incentive policy. Health Aff 35(5):784-790

Outterson K, Samora JB, Keller-Cuda K (2007) Will longer antimicrobial patents improve global public health? Lancet Infect Dis 7(8):559-566

Outterson K, Pogge T, Hollis A (2011) Combating antibiotic resistance through the Health Impact Fund. Boston Univ. School of Law, Law and Economics Research Paper No. 11-30. https://papers.ssrn. com/sol3/papers.cfm?abstract_id=1866768. Accessed 25 Nov 2018

President's Council of Advisors on Science and Technology (2014) Report to the President on combating antibiotic resistance. https:/www.cdc.gov/drugresistance/pdf/report-to-the-president-on-combatingantibiotic-resistance.pdf. Accessed 25 Nov 2018

Qian Y (2007) Do national patent laws stimulate domestic innovation in a global patenting environment? A cross-country analysis of pharmaceutical patent protection, 1978-2002. Rev Econ Stat 89(3):436-453

Rai J, Randhawa GK, Kaur M (2013) Recent advances in antibacterial drugs. Int J Appl Basic Med Res 3(1):3-10. https://www.ncbi.nlm.nih.gov/pmc/articles/PMC3678679/. Accessed 25 Nov 2018

Renwick MJ, Mossialos E (2018) What are the economic barriers of antibiotic R\&D and how can we overcome them? Expert Opin Drug Discov 10:889-892

Renwick MJ, Simpkin V, Mossialos E (2016) Targeting innovation in antibiotic drug discovery and development. European Observatory on Health Systems and Policies-Health Policy Series (45). http://www.euro.who.int/_data/assets/pdf_file/0003/315309/Targeting-innovation-antibiotic-drugd-and-d-2016.pdf. Accessed 25 Nov 2018

Renwick MJ, Brogan DM, Mossialos E (2017) A systematic review and critical assessment of incentive strategies for discovery and development of novel antibiotics. J Antibiot (Tokyo) 69(2):73-88

Rex JH, Outterson K (2016) Antibiotic reimbursement in a model delinked from sales. Lancet Infect Dis 4:500-505

Ridley DB, Grabowski HG, Moe JL (2006) Developing drugs for developing countries. Health Aff 25(2):313-324

Roin BN (2009) Unpatentable drugs and the standards of patentability. Tex Law Rev 87:503-570

Roin BN (2014) Intellectual property versus prizes: reframing the debate. Univ Chic Law Rev 81(3):999-1078

Rolain JM, Abat C, Jimeno MT, Fournier PE, Raoult D (2016) Do we need new antibiotics? Clin Microbiol Infect 22(5):408-415

Romandini R (2016) Flexibilities under TRIPS: an analysis of the proposal for reforming Brazilian patent law. John Marshall Rev Intell Prop Law 15:150-212

Romandini R (2018a) Art. 3(a) SPC legislation: an analysis of the CJEU's ruling in Teva (C-121/2017) and a proposal for its implementation. GRUR Int. 1:2019, pp 9-24

Romandini R (2018b) SPCs based on third-party marketing authorisation. In: Romandini R, Hilty RM, Kur A (eds) Study on the legal aspects of supplementary protection certificates in the EU, pp 260-262. https://ec.europa.eu/docsroom/documents/29524. Accessed 25 Nov. 2018

Sakakibara M, Branstetter L (2001) Do stronger patents induce more innovation? Evidence from the 1988 Japanese Patent Law. RAND J Econ 32(1):77-100

Santajit S, Indrawattana N (2016) Mechanisms of antimicrobial resistance in ESKAPE pathogens. Biomed Res Int 2475067. http://dx.doi.org/10.1155/2016/2475067. https://www.ncbi.nlm.nih.gov/ pmc/articles/PMC4871955/. Accessed 25 Nov 2018

Savic M, Årdal C (2018) A grant framework as a push incentive to stimulate research and development of new antibiotics. J Law Med Ethics 46(1):9-24

Schulman JP (2009) Patents and public health: the problems with using patent law proposals to combat antibiotic resistance. DePaul Law Rev 59(1):221-256

Sengupta S, Chattopadhyay MK, Grossart HP (2013) The multifaceted roles of antibiotics and antibiotic resistance in nature. Front Microbiol 4(47). https://www.frontiersin.org/articles/10.3389/fmicb.2013. 00047/full. Accessed 25 Nov 2018 
Sertkaya A, Eyraud J, Birkenbach A, Franz C, Ackerley N, Overton V, Outterson K (2014) Analytical framework for examining the value of antibacterial products. Boston Univ. School of Law, Public Law Research Paper No. 14-25

Sfeir MM (2018) The GAIN Act legislation to combat antimicrobial resistance: Where do we stand? Infect Control Hosp Epidemiol. https://doi.org/10.1017/ice.2018.252

Sharma P, Towse A (2010) New drugs to tackle antimicrobial resistance: analysis of EU policy options. Office of Health Economics-Occasional Paper 10/01. https://www.ohe.org/system/files/private/ publications $/ 330 \% 20-\% 20$ Occasional $\% 20$ Paper\%201\%20-\%20New\%20Drugs $\% 20$ to $\% 20$ Tackle $\%$ 20Antimicrobial\%20Resistance $\% 20 \% 20 \mathrm{WP} \% 20$ Sept $\% 201 \% 20 \% 28 \mathrm{PS} \% 29 \% 20$ Occasional\% 20paper\%2010-01.pdf?download=1. Accessed 25 Nov 2018

Simpkin VL, Renwick MJ, Kelly R, Mossialos E (2017) Incentivising innovation in antibiotic drug discovery and development. J Antibiot (Tokyo) 70(12):1087-1096

Sinha MS, Kesselheim AS (2016) Regulatory incentives for antibiotic drug development: a review of recent proposals. Bioorg Med Chem 24(24):6446-6451

So AD, Gupta N, Brahmachari SK, Chopra I, Munos B, Nathan C, Outterson K, Paccaud JP, Payne DJ, Peeling RW, Spigelman M, Weigelt J (2011) Towards new business models for R\&D for novel antibiotics. Drug Resist Updates 14(2):88-94. https:/www.reactgroup.org/uploads/publications/ other-publications/a-new-business-model.PDF. Accessed 25 Nov 2018

Sonderholm J (2009) Wild-card patent extensions as a means to incentivize research and development of antibiotics. J Law Med Ethics 37(2):240-246

Spellberg B (2014) The future of antibiotics. Crit Care 18(3):228-231

Spellberg B, Miller LG, Kuo MN, Bradley J, Scheld WM, Edwards JE Jr (2007) Societal costs versus saving from wild-card patent extension legislation to spur critically needed antibiotic development. Infection 35:167-174

Spellberg B, Blaser M, Guidos RJ, Boucher HW, Bradley JS, Eisenstein BI, Gerding D, Lynfield R, Reller LB, Rex J, Schwartz D, Septimus E, Tenover FC, Gilbert DN (2011) Infectious Diseases Society of America-combating antimicrobial resistance: policy recommendations to save lives. Clin Infect Dis 52:397-428

Spulber DF (2015) Public prizes versus market prices-Should contests replace patents? J Pat Trademark Office Soc 97:690-735

Stefanakis R, Robertson AS, Ponder EL, Moree M (2012) Analysis of neglected tropical disease drug and vaccine development pipelines to predict issuance of FDA priority review vouchers over the next decade. PLoS Negl Trop Dis 6(10):e1803

Stern S, Chorzelski S, Franken L, Völler S, Rentmeister H, Grosch B (2017) Boston Consulting Groupbreaking through the wall-a call for concerted action on antibiotics research and development. https://www.bundesgesundheitsministerium.de/fileadmin/Dateien/5_Publikationen/Gesundheit/ Berichte/GUARD_Follow_Up_Report_Full_Report_final.pdf. Accessed 25 Nov 2018

Sundberg A (2016) Alternative legal incentives for antibiotic research and development: the role and function of legal mechanisms. http://www.diva-portal.org/smash/get/diva2:969021/FULLTEXT01. pdf. Accessed 10 Dec 2018

Toole AA (2012) The impact of public basic research on industrial innovation: evidence from the pharmaceutical industry. Res Policy 41(1):1-12

Towse A, Kettler H (2005) A review of IP and non-IP incentives for R\&D for diseases of poverty. What type of innovation is required and how can we incentivise the private sector to deliver it? Working Paper for the Commission on Intellectual Property Rights, Innovation and Public Health (CIPIH), World Health Organization, Geneva. http://www.who.int/intellectualproperty/studies/A.Towse.pdf. Accessed 25 Nov 2005

US Department of Health and Human Services (2018) Generating antibiotic incentives now-required by Section 805 of the Food and Drug Administration Safety and Innovation Act. Public Law 112144. https://www.fda.gov/downloads/AboutFDA/CentersOffices/1605OfficeofMedicalProductsand Tobacco/CDER/UCM595188.pdf. Accessed 25 Nov 2018

Vernon JA (2005) Examining the link between price regulation and pharmaceutical R\&D investment. Health Econ 14(1):1-16

Webber D, Kremer M (2001) Perspectives on stimulating industrial research and development for neglected infectious diseases. Bull World Health Organ 79(8):735-741. http://www.who.int/ bulletin/archives/79(8)735.pdf. Accessed 25 Nov 2018 
White House (2014) National strategy for combating antibiotic-resistant bacteria. https:// obamawhitehouse.archives.gov/sites/default/files/docs/carb_national_strategy.pdf. Accessed 25 Nov 2018

Williams H (2012) Innovation inducement prizes: connecting research to policy. J Policy Anal Manag 31(3):752-775

Williams $\mathrm{H}$ (2016) Intellectual property rights and innovation: evidence from health care markets. Innov Policy Econ 16(1):53-87

Winegarden W (2016) Incenting the development of antimicrobial medicines to address the problem of drug-resistant infections. Pacific Research Institute Online Paper. https://www.pacificresearch.org/ wp-content/uploads/2017/06/AMRstudy_newfinal.pdf. Accessed 25 Nov 2018

World Health Organization (2017a) Antibacterial agents in clinical development—an analysis of the antibacterial clinical development pipeline, including tuberculosis. http://apps.who.int/iris/bitstream/ handle/10665/258965/WHO-EMP-IAU-2017.11-eng.pdf;jsessionid= 37B34E236963001EB63E5A0106EBA8CA?sequence=1. Accessed 25 Nov 2018

World Health Organization (2017b) Global priority list of antibiotic-resistant bacteria to guide research, discovery, and development of new antibiotics. http://www.who.int/medicines/publications/WHOPPL-Short_Summary_25Feb-ET_NM_WHO.pdf. Accessed 25 Nov 2018

World Health Organization (2017c) Prioritization of pathogens to guide discovery, research and development of new antibiotics for drug resistant bacterial infections, including tuberculosis. https:// www.who.int/medicines/areas/rational_use/PPLreport_2017_09_19.pdf?ua=1. Accessed 25 Nov 2018

World Health Organization (2018) Global antimicrobial resistance surveillance system (GLASS) report 2016-2017. http://apps.who.int/iris/bitstream/handle/10665/259744/9789241513449-eng.pdf;jsessionid= E856175994119169A47817742AF37AAA?sequence=1. Accessed 25 Nov 2018

Wright BD (1983) The economics of invention incentives: patents, prizes, and research contracts. Am Econ Rev 73(4):691-707

Wright GD (2016) Antibiotic adjuvants: rescuing antibiotics from resistance. Trends Microbiol 24:862-871

Yin W (2008) Market incentives and pharmaceutical innovation. J Health Econ 27(4):1060-1077

Yin N (2017) Pharmaceuticals, incremental innovation and market exclusivity. Mimeo

Zuleeg M (1992) Betrachtung zum Gleichheitssatz im Europäischen Gemeinschaftsrecht. In: Baur JF, Müller-Graff PC, Zuleeg M (eds) Europarecht, Energierecht, Wirtschaftsrecht—Festschrift für Bodo Börner. Cologne, Berlin, Bonn, p 473 et seq

Publisher's Note Springer Nature remains neutral with regard to jurisdictional claims in published maps and institutional affiliations. 